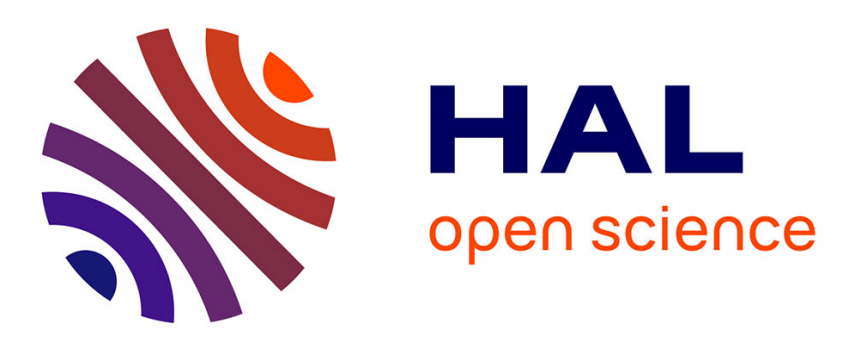

\title{
An Easy, Stereoselective Synthesis of Hexahydroisoindol-4-ones under Phosphine Catalysis
}

Deepti Duvvuru, Jean-François Betzer, Pascal Retailleau, Gilles Frison, Angela Marinetti

\section{- To cite this version:}

Deepti Duvvuru, Jean-François Betzer, Pascal Retailleau, Gilles Frison, Angela Marinetti. An Easy, Stereoselective Synthesis of Hexahydroisoindol-4-ones under Phosphine Catalysis. Advanced Synthesis and Catalysis, 2011, 353 (2-3), pp.483-493. 10.1002/adsc.201000701 . hal-00554156

\author{
HAL Id: hal-00554156 \\ https://hal.science/hal-00554156
}

Submitted on 3 Mar 2011

HAL is a multi-disciplinary open access archive for the deposit and dissemination of scientific research documents, whether they are published or not. The documents may come from teaching and research institutions in France or abroad, or from public or private research centers.
L'archive ouverte pluridisciplinaire HAL, est destinée au dépôt et à la diffusion de documents scientifiques de niveau recherche, publiés ou non, émanant des établissements d'enseignement et de recherche français ou étrangers, des laboratoires publics ou privés. 


\title{
An Easy, Stereoselective Synthesis of Hexahydroisoindol-4-ones under Phosphine Catalysis
}

\author{
Deepti Duvvuru, ${ }^{\mathrm{a}}$ Jean-François Betzer, ${ }^{\mathrm{a}, *}$ Pascal Retailleau, ${ }^{\mathrm{a}}$ Gilles Frison ${ }^{\mathrm{b}}$ and \\ Angela Marinetti ${ }^{\mathrm{a}, *}$
}

a Institut de Chimie des Substances Naturelles, CNRS UPR 2301 - 1, av. de la Terrasse, 91198 Gif-sur-Yvette Cedex, France. Fax : (+33) 0169077247 ; Phone : (+33) 0169823036 ; e-mail : jean-francois.betzer@icsn.cnrs-gif.fr; angela.marinetti@icsn.cnrs-gif.fr

b Laboratoire des Mécanismes Réactionnels - CNRS UMR 7651, Ecole Polytechnique, Département de Chimie, 91128 Palaiseau Cedex (France)

Received:

Supporting information for this article is available on the WWW under http://dx.doi.org/10.1002/adsc.200

Abstract. A new synthetic approach to hexahydroisoindol4-ones is reported, based on the formal [3+2] cyclization reaction between $N$-arylsulfonylimines and cyclic conjugated dienes, under phosphine catalysis. Key substrates are 3-vinylcyclohex-2-enones with electronwithdrawing substituents (ester, amido, cyano, phosphoryl and keto groups) on the exocyclic double bond, which afford the three atom synthons for the construction of the pyrroline ring. Total syn stereoselectivity is observed in these annulations. The scope of the reaction has been demonstrated and mechanistic issues are considered, based on deuteration experiments and DFT calculations.

Keywords: phosphine organocatalysis; conjugated dienes; imines; hexahydroisoindolones; [3+2] annulations

\section{Introduction}

Isoindoline units are commonly found in biologically relevant compounds and drug candidates displaying a remarkable variety of activities. ${ }^{[1]}$ The related perhydroisoindol-4-ones have also found applications as core scaffolds or synthetic intermediates in medicinal chemistry. ${ }^{[2]}$ Common synthetic strategies toward saturated fused bicyclic amines of this class mainly involve the 1,3-dipolar cycloaddition of azomethine ylides on suitable cyclic olefins $^{[3]}$ or Diels-Alder type reactions on maleimide. $^{[4,5]}$

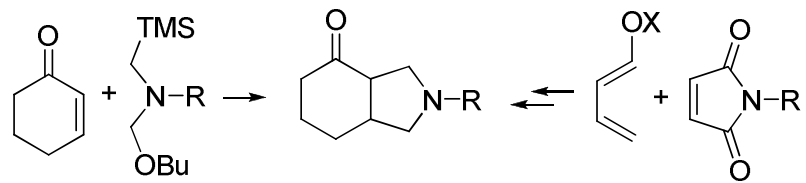

Scheme 1 Synthetic approaches to perhydroisoindol-4-one scaffolds.

A new, alternative and practical synthesis of hexahydro- $4 \mathrm{H}$-isoindol-4-one derivatives is reported hereafter, based on phosphine catalyzed [3+2] cyclizations ${ }^{[6]}$ which involve imines and dienes as the two atom and three atom components respectively. The method has been unexpectedly brought to light while expanding the scope of the recently disclosed reaction between electron-poor conjugated dienes and imines, under phosphine catalysis, shown in Scheme $2 .{ }^{[7]}$ In this reaction, starting from acyclic conjugated dienes properly activated by electronwithdrawing groups on both ends, 3-pyrrolines were produced. ${ }^{[8}$ The cyclization took place selectively on the double bond substituted by the ester function, following to formal activation of this bond by the nucleophilic phosphine.

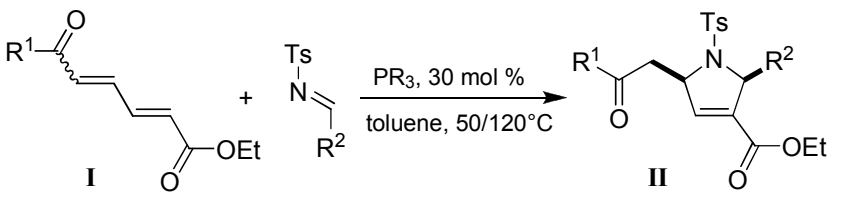

$\mathrm{R}^{1}=$ alkyl or aryl

$\mathrm{PR}_{3}=\mathrm{PBu}_{3}$ or $\mathrm{PMePh}_{2}$

Scheme 2. Synthesis of pyrrolines from conjugated dienes and imines under phosphine catalysis. ${ }^{[7]}$

As a logical extension of this previous work, the same strategy has been applied then to conjugated dienes where one of the double bonds is embedded in a cyclic moiety. These experiments have allowed an 
efficient access to the hexahydroisoindol-4-one scaffolds 3 to be implemented, as shown hereafter.

\section{Results and Discussion}

With the purpose of expanding the scope of the phosphine promoted annulations reactions between imines and conjugated dienes shown in Scheme 2, ${ }^{[7]}$ we have considered the known 3-(2-methoxycarbonylvinyl)-2-cyclo-hexenone $\mathbf{1 a}^{[9]}$ as a model substrate for initial studies. Diene 1a has been reacted with $N$-tosyl-benzaldimine in the presence of trivalent phosphines as nucleophilic catalysts (Scheme 3). A clean reaction took place indeed, leading to the bicyclic pyrroline 3a, whose formation has been optimized by a rapid screening of catalysts $\left(\mathrm{PBu}_{3}\right.$, $\left.\mathrm{PMe}_{3}, \mathrm{PMe}_{2} \mathrm{Ph}, \mathrm{PMePh}_{2}, \mathrm{PPh}_{3}, \mathrm{P}(i-\mathrm{Bu})_{3}\right)$ and reaction conditions. The optimized conditions include the use of $\mathrm{PBu}_{3}$ as the catalyst, a 2:1 imine:diene ratio, polar solvents (methyl ethyl ketone or $t-\mathrm{BuOH}$ ) and a reaction temperature of $80^{\circ} \mathrm{C}$. In MEK, with a 10 mol\% amount of the phosphorus catalyst, total conversion could be attained after $18 \mathrm{~h}$.

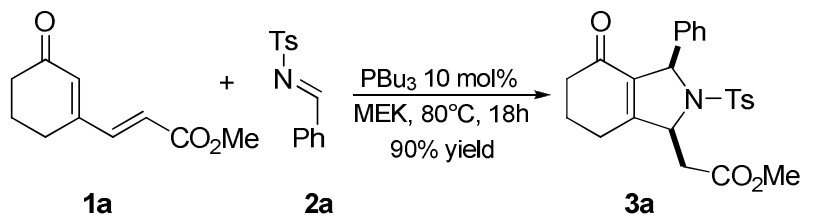

Scheme 3. Phosphine promoted annulation between the cyclic diene $\mathbf{1 a}$ and imine $\mathbf{2 a}$.

The molecular structure of $\mathbf{3 a}$ has been assigned at first by NMR and unambiguously established then by $\mathrm{X}$-ray crystallography on the corresponding hydrazone 3a' (Figure 1) ${ }^{[10]}$ NMR and structural data indicate that the reaction affords exclusively the syn isomer of the bicyclic fused pyrroline, with total chemo- and stereoselectivity.

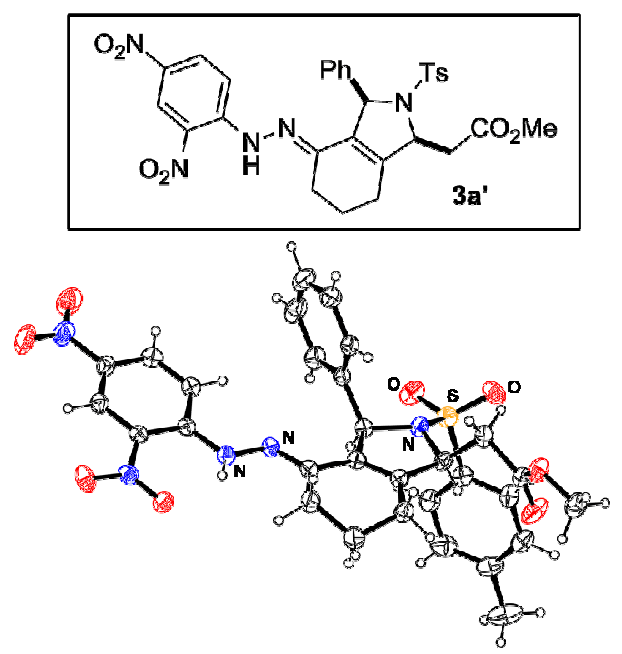

Figure 1. X-ray crystal structure of hydrazone 3a'.
The outcome of this cyclization reaction highlights a stricking chemodivergent behaviour of the cyclic diene 1a with respect to the acyclic analogue I, as far as cyclization takes place on the enone function of 1a while it was shown to take place on the enoate function of $\mathbf{I}$. This result rises some mechanistic concerns which will be discussed briefly in final section of this paper.

Since a variety of hexahydroisoindol-4-ones might be easily available from simple starting materials following the synthetic strategy typified in Scheme 1, we next examined the scope of this catalytic process. Representative results are depicted in Table 1 . The cyclization reaction can be performed with tosylimines bearing substituted aryls, heteroaryls (entry 3) and alkyl groups (entry 7). It also tolerates $p$-chloro- and $p$-nitro phenylsulfonyl activating groups on the nitrogen atom (entries 8,9), while $N$ DPP imines failed to react. Most reactions take place at $80^{\circ} \mathrm{C}$ with a $10 \mathrm{~mol} \%$ amount of $\mathrm{PBu}_{3}$, but in some cases it may be advantageous to increase the catalyst amount or the temperature in order to increase the conversion rates. Both methyl ethyl ketone (MEK) and $t-\mathrm{BuOH}$ are suitable solvents. According to NMR analyses, the crude final mixtures contain $\mathbf{3}$ and, possibly, some residual starting material, with only minor amounts of side products.

Table 1. Phosphine promoted synthesis of the hexahydroisoindol-4-ones 3: variations of the imine partner.

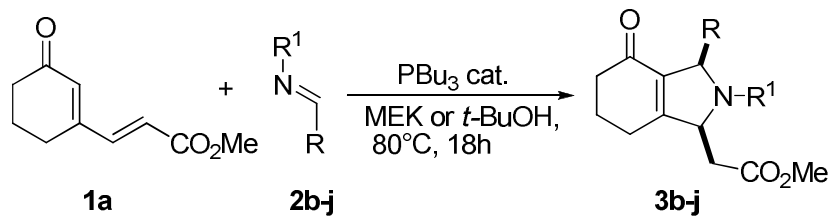

\begin{tabular}{llllccl}
\hline & Imine & $\mathrm{R}$ & $\mathrm{R}^{1}$ & $\begin{array}{c}\mathrm{PBu}_{3} \\
\%\end{array}$ & Prod. & $\begin{array}{l}\text { Yield } \\
\%\end{array}$ \\
\hline 1 & $\mathbf{2 b}$ & $4-\mathrm{Cl}-\mathrm{C}_{6} \mathrm{H}_{4}$ & $\mathrm{Ts}$ & 10 & $\mathbf{3 b}$ & 93 \\
2 & $\mathbf{2 c}$ & $4-\mathrm{CF}_{3}-\mathrm{C}_{6} \mathrm{H}_{4}$ & $\mathrm{Ts}$ & 30 & $\mathbf{3 c}$ & 78 \\
3 & $\mathbf{2 d}$ & $2-$ thienyl & $\mathrm{Ts}$ & 10 & $\mathbf{3 d}$ & 76 \\
4 & $\mathbf{2 e}$ & $4-\mathrm{MeO}-\mathrm{C}_{6} \mathrm{H}_{4}$ & $\mathrm{Ts}$ & 30 & $\mathbf{3 e}$ & $82^{[\mathrm{b}]}$ \\
5 & $\mathbf{2 f}$ & 1-naphthyl & $\mathrm{Ts}$ & 10 & $\mathbf{3 f}$ & 83 \\
6 & $\mathbf{2 g}$ & $p-\mathrm{NO}_{2}-\mathrm{C}_{6} \mathrm{H}_{4}$ & $\mathrm{Ts}$ & 30 & $\mathbf{3 g}$ & $47^{[\mathrm{c}]}$ \\
7 & $\mathbf{2 h}$ & $i-\mathrm{Pr}$ & $\mathrm{Ts}$ & 30 & $\mathbf{3 h}$ & $71^{[\mathrm{d}]}$ \\
8 & $\mathbf{2 i}$ & $\mathrm{Ph}$ & $4-\mathrm{Cl}-\mathrm{PhSO}_{2}$ & 10 & $\mathbf{3 i}$ & 82 \\
9 & $\mathbf{2 j}$ & $\mathrm{Ph}$ & $4-\mathrm{NO}_{2}-\mathrm{PhSO}_{2}$ & 10 & $\mathbf{3 j}$ & 44 \\
\hline
\end{tabular}

[a] Conditions: reactions have been performed at a 0.3 mmol scale, under Ar, in degassed MEK (1 mL, entries 1-5 and 8$)$ or $t$-BuOH $(1 \mathrm{~mL}$, entries 6,7,9); diene:imine ratio = $1: 1.5$, unless otherwise stated. [b] Reaction temperature: $100^{\circ} \mathrm{C}$. $[\mathrm{c}]$ diene:imine ratio $=1: 2$. [d] Diene:imine ratio $=$ $1: 3$

The fused bicyclic pyrrolines $\mathbf{3 b}$-j were obtained as single isomers which have been assigned as the syn isomers by analogy to 3a, based on their typical ${ }^{1} \mathrm{H}$ NMR pattern. The two NCH units display signals at $\delta$ $=5.6(\mathrm{~d}, J \sim 1.2 \mathrm{~Hz}, \mathrm{NCHAr})$ and $5.0 \mathrm{ppm}$, while the chemical shifts of the $\mathrm{CH}_{2}-\mathrm{CO}_{2} \mathrm{Me}$ units are at about 
3 ppm (AB system with ${ }^{2} \mathbf{J}_{\mathrm{H}-\mathrm{H}} \sim 16 \mathrm{~Hz},{ }^{3} \mathrm{~J}_{\mathrm{H}-\mathrm{H}} \sim 4$ and $\sim 8$ $\mathrm{Hz})$.

Further efforts have been directed then toward modulation of the withdrawing group of the diene moiety (Scheme 4). Dienes 5a-e bearing keto, amido, cyano and diethylphosphoryl functions on the external double bond, have been prepared by Heck reaction from either 3-tosyloxy- or 3-bromo-2cyclohexenones and suitably functionalized olefins. They have been reacted then with $N$ tosylbenzaldimine in the presence of $\mathrm{PBu}_{3}$ in MEK.

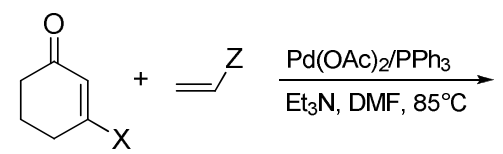

4a, $X=O T s$

4b, $X=\mathrm{Br}$

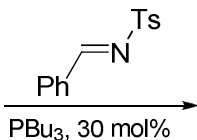

$\mathrm{PBu}_{3}, 30 \mathrm{~mol} \%$

MEK, $100^{\circ} \mathrm{C}, 18 \mathrm{~h}$

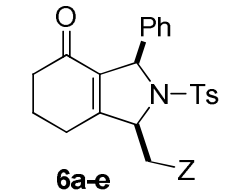

6a $(91 \%)$
6b $(47 \%)$
6c $(68 \%)$
6d $(32 \%)$

$6 \mathrm{e}(41 \%)$
Scheme 4. Synthesis of hexahydroisoindol-4-ones with various functional groups tethered to the 1-position.

Compared to 1a, the new dienic substrates $\mathbf{5}$ displayed lower reactivity, nevertheless the desired hexahydroisoindol-4-ones 6 could be obtained in moderate to good yields for reactions carried out at $100^{\circ} \mathrm{C}$, with about $30 \mathrm{~mol} \%$ catalyst. ${ }^{[11]}$ In these reactions also, the final products were isolated as single isomers.

In additional experiments, variation of the ring size of the dienic substrate has been attempted by considering the five-member cyclic diene $\mathbf{7}$ as a possible reaction partner. Diene $\mathbf{7}$ has been prepared by Heck reaction between methyl acrylate and 3iodocyclopent-2-enone, ${ }^{[12]}$ with $\mathrm{Pd}(\mathrm{OAc})_{2} /$ $\mathrm{Ph}_{2} \mathrm{P}\left(\mathrm{CH}_{2}\right)_{3} \mathrm{PPh}_{2}$ as the catalyst. In the usual conditions, the reaction of 7 with $N$ tosylbenzaldimine failed to give the expected pyrroline displaying a bicyclo-[3.3.0] scaffold. It produced however the aza-Morita-Baylis-Hillman adduct $\mathbf{8}$ in $70 \%$ yield.

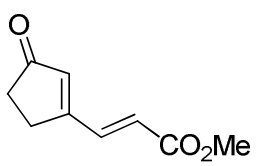

7

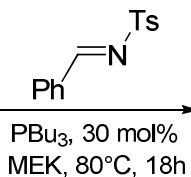

MEK, $80^{\circ} \mathrm{C}, 18 \mathrm{~h}$

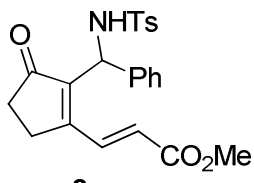

8
Scheme 5. Aza-Morita-Baylis-Hillman type reaction of vinylcyclopentenone $\mathbf{7}$ and $\mathrm{N}$-tosylbenzaldimine.

The aza-MBH reaction takes place selectively on the enone function, despite the fact that this will involve formal activation of a trisubstituted double bond by the phosphorus nucleophile. As far as we know, this is an unprecedented example of phosphine promoted aza-MBH reaction on a $\beta$-substituted cyclic enone.

In summary, results in Scheme 5 show that, in the case of cyclopentenone derivatives, the annulation reaction is no longer competitive with the direct elimination of the phosphine leading to the classical aza-MBH adduct. Therefore, the application field of our method is restricted so far to the synthesis of the [4.3.0]-bicyclic moiety of isoindolinones.

Finally, in order to expand the synthetic utility of the method, we have checked the feasibility of nitrogen deprotection in the final bicyclic product. To this end, we have considered the $N$-nosyl protected tetrahydroisoindolone $\mathbf{3 j}$, since mild deprotection protocols are known for the nosyl group. The nosyl group could be removed actually by reaction of $\mathbf{3 j}$ with thiophenol in the presence of sodium carbonate (Scheme 6). ${ }^{[13]}$

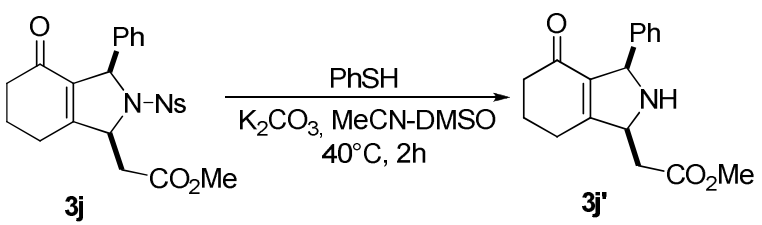

Scheme 6. Removal of the nosyl protecting group from isoindoline $\mathbf{3 j}$.

The final secondary amine has been isolated from the crude reaction mixture, in pure form and good yield $(66 \%)$, by extraction in acid solution. NMR data show that the bicyclic pyrroline ring is retained during the deprotection procedure.

\section{Mechanistic considerations}

On a mechanistic point of view, the most straightforward pathway for building the tetrahydroisoindolines $\mathbf{3}$ (or $\mathbf{6}$ ) would involve addition of the phosphorus nucleophile to the intracyclic double bond of $\mathbf{1}$ or $\mathbf{5}$ (path $a$ in Scheme 7), followed by nucleophilic addition of $\underline{\mathbf{A}}$ to the imine. Intermediate A1 should undergo then an intramolecular Michael type addition leading to A2. A formal [1,4]-proton shift will then convert $\mathbf{A 2}$ into $\mathbf{A 3}$ and create a negative charge $\beta$-to the phosphorus centre. The phosphine elimination step achieves the cyclization process. This mechanism implies the preferential activation of the internal, trisubstituted double bond of the starting diene, vs. activation of the disubstituted enoate function via intermediate $\underline{\mathbf{B}}$ (Scheme 7b). This is rather unexpected, especially when considering that the related phosphine promoted aza-Morita-Baylis-Hillman reactions seldom apply to $\beta$-substituted Michael acceptors. ${ }^{[14,15]}$ 
(a)

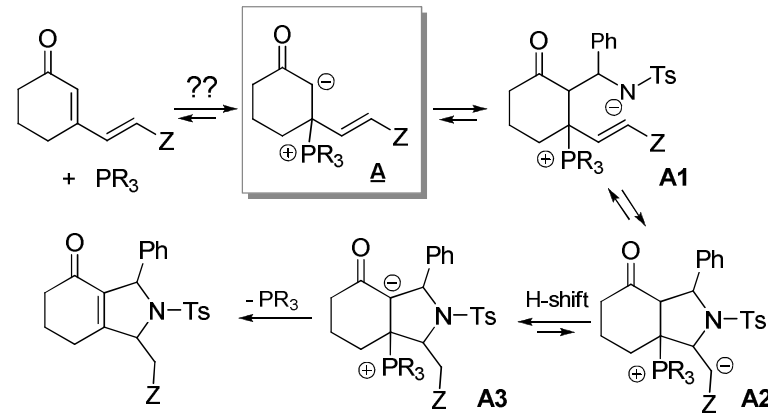

(b)

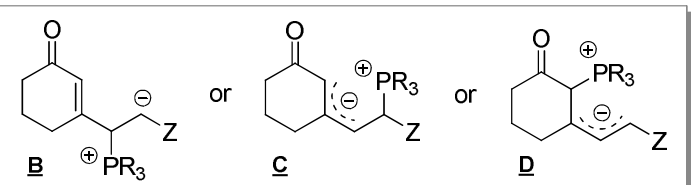

Scheme 7. (a) A straightforward mechanism for the annulation reaction. (b) Alternative zwitterionic intermediates generated by phosphine addition to the conjugated dienes.

Therefore, in order to get additional information on possible reaction intermediates, the cyclization between 5a and $\mathbf{2 a}$ has been performed in the presence of excess $\mathrm{D}_{2} \mathrm{O}$, as shown in Scheme 8 . Since $\mathrm{H}$-shifts are known to be mediated by traces of water, ${ }^{[16]}$ deuterium is expected to be incorporated on all positions involved in $\mathrm{H}$-shift processes.

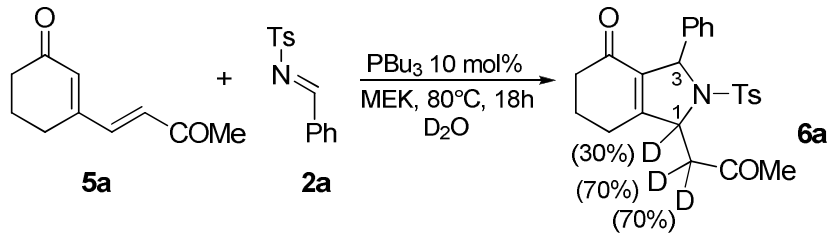

Scheme 8. Cyclization reaction in the presence of $\mathrm{D}_{2} \mathrm{O}$

The sample of $\mathbf{6 a}$ isolated from this experiment contains a significant amount of deuterium $(70 \%)$ at the methylene carbon $\alpha$ to the COMe function. This was fully anticipated, due to the postulated formation of intermediate A2. However, deuterium has been partially incorporated also at the $\mathrm{C} 1$ carbon of $\mathbf{6 a}$ (30\%) while the C3 moiety contains only protons. The mechanism shown in Scheme $7 \mathrm{a}$ does not account, by itself, for the observed deuterium distribution, since it does not involve $\mathrm{H}$-exchanges at the $\mathrm{C} 1$ carbon.

Therefore, less straightforward mechanisms can't be excluded so far, which might involve initial addition of the phosphorus catalyst to other sites of the dienic moiety.

According to Hückel and quantum chemical calculations, the LUMO orbital of conjugated dienes such as $1 \mathbf{a}$ or $\mathbf{5 a}$ is distributed along the dienic unit, with roughly identical coefficients on the four atoms (Figure 2).

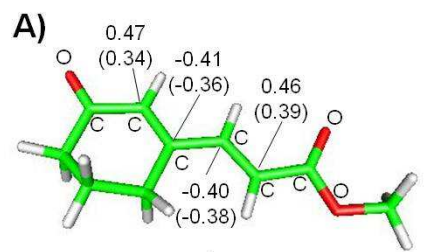

B) $\quad 0.47$

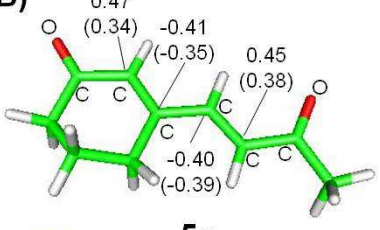

$1 \mathrm{a}$
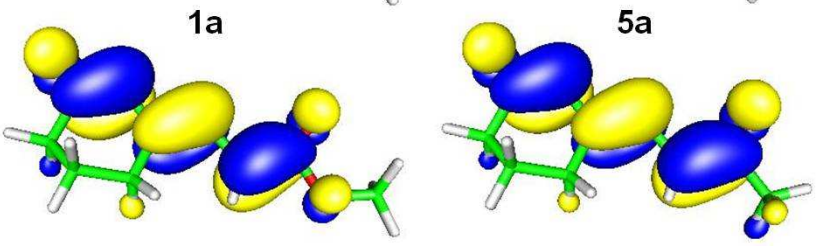

Figure 2. LUMO coefficients for the dienic carbon atoms at the HF and Hückel (in bracket) levels (top) and qualitative view of the LUMO at the DFT level (bottom) for A) 1a and B) $5 \mathbf{a}$.

Consequently, the zwitterionic species $\underline{\mathbf{B}}, \underline{\mathbf{C}}$ and $\underline{\mathbf{D}}$ (Scheme 7b) might also be formed by addition of the nucleophilic phosphine to the $\alpha, \gamma$ and $\delta$ positions of the dienic ketone. They might enter a catalytic cycle or, alternatively, their reversible formation might induce $H / D$ exchange reactions accounting for the observed D-distribution in the final product 6a (Scheme 8).

The reversible addition of tributylphosphine to the diene has been evidenced by the H/D exchange experiment shown in Scheme 9.

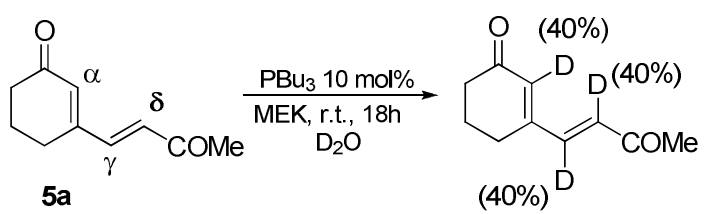

Scheme 9. $\mathrm{PBu}_{3}$-promoted, $\mathrm{H} / \mathrm{D}$ exchange reactions.

When $5 \mathbf{a}$ was stirred at r.t. in the presence of $\mathrm{PBu}_{3}$ and $\mathrm{D}_{2} \mathrm{O}$, deuterium has been incorporated in comparable amounts on the $\alpha, \gamma$ and $\delta$ carbons of the starting dienic unit.

Thus, experimental data and calculations support the hypothesis of an initial, reversible addition of the phosphorus nucleophile to various positions of the dienic substrate generating different zwitterionic adducts. The reaction outcome will be determined then at a later step of the catalytic cycle.

Additional studies are required to enlighten the precise mechanism of these cyclization reactions.

\section{Conclusion}

This work demonstrates that the phosphinemediated organocatalytic annulations between 3vinylcyclohexenones and $N$-arylsulfonylimines produce hexahydroisoindol-4-ones with various functional groups connected to the $\mathrm{C} 1$-carbon by a $\mathrm{CH}_{2}$ spacer. This represents a new, easy and 
stereoselective access to isoindoline derivatives with an unprecedented substitution scheme. Insights into the reaction mechanism have been obtained from deuteration experiments and DFT calculations which demonstrate the reversible addition of the phosphorus catalyst to the dienic unit.

The method proved unsuitable for the direct synthesis of the analogous 2-aza-bicyclo[3.3.0] units from cyclopentenone derivatives. Cyclic substrates with different ring sizes are now considered in ongoing studies.

\section{Experimental Section}

Synthesis of the conjugated dienes 1,5 and 7 via Heck reactions. (a) Dienes $\mathbf{1 a}$ and 5a,c,e have been prepared from tosylate $\mathbf{4 a}$ according to the reported method. ${ }^{[9]}$ Representative procedure: A mixture of tosylate $4 \mathbf{a}$ (4.0 g, $15 \mathrm{mmol})$, a suitable olefin $\mathrm{H}_{2} \mathrm{C}=\mathrm{CHZ}(22 \mathrm{mmol}), \mathrm{Et}_{3} \mathrm{~N}$ $(3.3 \mathrm{~mL}, 24 \mathrm{mmol}), \mathrm{Pd}(\mathrm{OAc})_{2}(50.6 \mathrm{mg}, 0.22 \mathrm{mmol})$ and $\mathrm{PPh}_{3} \quad(59 \mathrm{mg}, \quad 0.22 \mathrm{mmol}$ ) in degazed N,Ndimethylacetamide $(11 \mathrm{~mL}) / \mathrm{DMF}(4.5 \mathrm{~mL})$ was heated at $105^{\circ} \mathrm{C}$ under argon for $24 \mathrm{~h}$. The reaction mixture was routinely monitored by ${ }^{1} \mathrm{H}$ NMR. If needed, additional amounts of $\mathrm{Pd}(\mathrm{OAc})_{2} / \mathrm{PPh}_{3}$ were added to achieve total conversion of the starting tosylate.After aqueous workup with $\mathrm{HCl} 0.5 \mathrm{~N}$, the organic layer was washed with $\mathrm{NaHCO}_{3}$ and water and evaporated to dryness. The final product was purified by column chromatography on silica gel.

\section{(E)-N,N-dimethyl-3-(3-oxocyclohex-1-enyl)acrylamide}

(5c) has been obtained in $59 \%$ yield $(0.85 \mathrm{~g}, 4.4 \mathrm{mmol})$ from tosylate 4a $(2.0 \mathrm{~g}, 7.5 \mathrm{mmol})$ and $\mathrm{N}, \mathrm{N}$-dimethyl acrylamide $(1.1 \mathrm{~g}, 11 \mathrm{mmol}$ ) (Method $a$ ). The final product has been purified by column chromatography with ethyl acetate $\left(\mathrm{R}_{\mathrm{f}}=0.2\right)$ as the eluent. ${ }^{1} \mathrm{H} \mathrm{NMR}\left(\mathrm{CDCl}_{3}\right): \delta 7.27$ $(\mathrm{d}, J=15.6 \mathrm{~Hz}, 1 \mathrm{H}), 6.69(\mathrm{~d}, J=15.6 \mathrm{~Hz}, 1 \mathrm{H}), 6.11(\mathrm{~s}, 1 \mathrm{H})$ $3.10(\mathrm{~s}, 3 \mathrm{H}), 3.01(\mathrm{~s}, 3 \mathrm{H}), 2.50-2.39(\mathrm{~m}, 4 \mathrm{H}), 2.09-2.00(\mathrm{~m}$, $2 \mathrm{H}) ;{ }^{13} \mathrm{C} \mathrm{NMR}\left(\mathrm{CDCl}_{3}\right): \delta 199.8(\mathrm{CO}), 165.6(\mathrm{CO}-\mathrm{N}), 154.5$ (C), 141.9, 131.4, 123.5, $37.6(\mathrm{Me}), 37.4(\mathrm{Me}), 35.9,25.1$, $22.1 \mathrm{ppm}$.

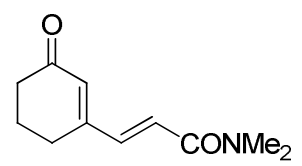

(E)-diethyl 2-(3-oxocyclohex-1-enyl)vinylphosphonate (5e) has been obtained in $73 \%$ yield $(1.3 \mathrm{~g}, 5.0 \mathrm{mmol})$ from tosylate $\mathbf{4 a}(2.0 \mathrm{~g}, 7.5 \mathrm{mmol})$ and diethyl vinylphosphonate $(1.1 \mathrm{~g}, 6.8 \mathrm{mmol}) .{ }^{1} \mathrm{H} \mathrm{NMR}\left(\mathrm{CDCl}_{3}\right): \delta 7.12\left(\mathrm{dd}, J_{\mathrm{H}-\mathrm{P}}=21.8\right.$ $\mathrm{Hz}, J=17.4 \mathrm{~Hz}, 1 \mathrm{H}), 6.11\left(\mathrm{t}, J_{\mathrm{H}-\mathrm{P}} \sim J_{\mathrm{H}-\mathrm{H}}=17.7 \mathrm{~Hz}, 1 \mathrm{H}\right)$, $6.06(\mathrm{~s}, 1 \mathrm{H}), 4.06(\mathrm{~m}, 4 \mathrm{H}), 2.40\left(\mathrm{~m}, 4 \mathrm{H}, \mathrm{OCH}_{2}\right), 2.03(\mathrm{~m}$, $2 \mathrm{H}), 1.29(\mathrm{t}, J=7.1 \mathrm{~Hz}, 6 \mathrm{H}, \mathrm{Me}) \mathrm{ppm} .{ }^{13} \mathrm{C} \mathrm{NMR}\left(\mathrm{CDCl}_{3}\right)$ : $\delta 199.7(\mathrm{CO}) 153.8(\mathrm{~d}, J=23.5 \mathrm{~Hz}), 147.9(\mathrm{~d}, J=6.6 \mathrm{~Hz})$, $132.0(=\mathrm{CH}), 121.2(\mathrm{~d}, J=189 \mathrm{~Hz}, \mathrm{PCH}), 62.1(\mathrm{~d}, J=6.0$ $\left.\mathrm{Hz}, \mathrm{OCH}_{2}\right), 37.6,24.5,21.9,16.3(\mathrm{~d}, J=6.1 \mathrm{~Hz}, \mathrm{Me}) ;{ }^{31} \mathrm{P}$ $\mathrm{NMR}\left(\mathrm{CDCl}_{3}\right): \delta 17 \mathrm{ppm}$.

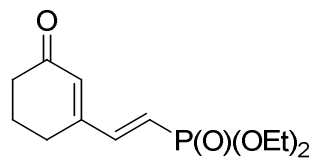

(b) Dienes $\mathbf{5 b}$ and $\mathbf{5 d}$ have been prepared by Heck reactions between 3-bromocyclohex-2-enone $\mathbf{4 b}$ and the corresponding olefins, following the same procedure. The reactions are completed after heating for $2 \mathrm{~h}$ at $85^{\circ} \mathrm{C}$.

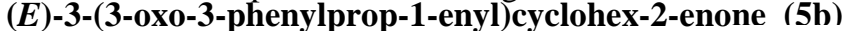
has been obtained in $71 \%$ vield $(0.92 \mathrm{~g})$ from the bromide 4h $(1.0 \mathrm{~g}, 5.7 \mathrm{mmol})$ and phenyl vinyl ketone $(1.0 \mathrm{~g}, 7.5$ mmol). $\mathrm{H}$ NMR $\left(\mathrm{CDCl}_{3}\right): \delta 7.90(\mathrm{~d}, J=7.0 \mathrm{~Hz}, 2 \mathrm{H}), 7.53$ $(\mathrm{m}, 1 \mathrm{H}), 7.4(\mathrm{~m}, 2 \mathrm{H}), 7.39(\mathrm{~d}, J=17 \mathrm{~Hz}, 1 \mathrm{H}), 7.21(\mathrm{~d}, J=$ $17 \mathrm{~Hz}, 1 \mathrm{H}), 6.20(\mathrm{~s}, 1 \mathrm{H}), 2.54(\mathrm{~m}, 2 \mathrm{H}), 2.43(\mathrm{~m}, 2 \mathrm{H}), 2.06$ (m, 2H) ppm.

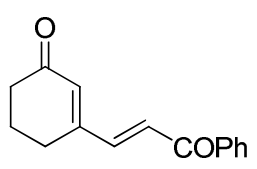

(E)-3-(3-oxocyclohex-1-enyl)acrylonitrile (5d) has been obtained in $44 \%$ yield $(0.37 \mathrm{~g})$ from bromide $4 \mathrm{~b}(1.0 \mathrm{~g}, 5.7$ mmol) and acrylonitrile $(0.40 \mathrm{~mL}, 6 \mathrm{mmol})$ after purification by column chromatography with an heptaneethyl acetate gradient as the eluent. ${ }^{1} \mathrm{H} \mathrm{NMR}\left(\mathrm{CDCl}_{3}\right)$ : $\delta 7.13(\mathrm{~d}, J=16.5 \mathrm{~Hz}, 1 \mathrm{H}), 6.13(\mathrm{~s}, 1 \mathrm{H}), 5.75(\mathrm{~d}, J=16.5$ $\mathrm{Hz}, 1 \mathrm{H}), 2.50-2.42(\mathrm{~m}, 4 \mathrm{H}), 2.11(\mathrm{~m}, 2 \mathrm{H}) \mathrm{ppm}$.

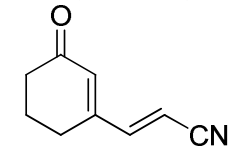

(c) (E)-methyl 3-(3-oxocyclopent-1-enyl)prop-2-enoate (7). Diene 7 has been prepared by Heck reaction between 3iodocyclopent-3-enone ${ }^{[12 f}$ and methyl acrylate. A mixture of 3-iodocyclopent-3-enone $(0.50 \mathrm{~g}, 2.4 \mathrm{mmol})$, methyl acrylate $(0.54 \mathrm{~mL}, 6 \mathrm{mmol}), \mathrm{Pd}(\mathrm{OAc})_{2}(27 \mathrm{mg}, 0.12 \mathrm{mmol})$, bis(diphenylphosphino)propane $(25 \mathrm{mg}, 0.06 \mathrm{mmol}), \mathrm{Et}_{3} \mathrm{~N}$ $(0.65 \mathrm{~mL}, 4.8 \mathrm{mmol})$ in DMF $(10 \mathrm{~mL})$ have been heated at $85^{\circ} \mathrm{C}$ for $16 \mathrm{~h}$. After aqueous workup with $\mathrm{HCl} 0.5 \mathrm{~N}$, the organic laver was washed with $\mathrm{NaHCO}_{2}$ and water and evanorated to drvness. The final nroduct 7 was nurified bv column chromatography on silica gel with an heptane/ethyl acetate oradient $\left(\mathbf{R}_{\boldsymbol{f}}=0.3\right.$ in heptane/ethyl acetate $\left.1: 1\right)$. Yield: $0.20 \mathrm{~g}, 50 \%$. ${ }^{1} \mathrm{H}$ NMR $\left(\mathrm{CDCl}_{3}\right): \delta 7.63(\mathrm{~d}, J=15.9$ $\mathrm{Hz}, 1 \mathrm{H}), 6.30(\mathrm{~d}, J=15.9 \mathrm{~Hz}, 1 \mathrm{H}), 6.29(\mathrm{~s}, 1 \mathrm{H}), 3.78(\mathrm{~s}$, 3H), $2.7(\mathrm{~m}, 2 \mathrm{H}), 2.49(\mathrm{~m}, 2 \mathrm{H}) ;{ }^{13} \mathrm{C}$ NMR $\left(\mathrm{CDCl}_{3}\right): \delta 208.8$ (CO), $168.3\left(\mathrm{CO}_{2} \mathrm{Me}\right), 166.2(\mathrm{C}), 138.6(\mathrm{CH}), 136.1(\mathrm{CH})$, $125.0(\mathrm{CH}), 52.3(\mathrm{OMe}), 35.1\left(\mathrm{CH}_{2}\right), 27.0\left(\mathrm{CH}_{2}\right) \mathrm{ppm}$.

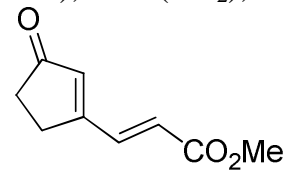

Phosphine promoted cyclization reactions. General Procedure: $\mathrm{PBu}_{3}(25-75 \mu \mathrm{mol})$ was added to a mixture of diene $(0.25 \mathrm{mmol})$ and imine $(0.50 \mathrm{mmol})$ in methyl ethyl ketone (or $t-\mathrm{BuOH})(1 \mathrm{~mL})$ under argon. The mixture was heated overnight $(18 \mathrm{~h})$ at the given temperature (see Schemes 3, 4 and Table 1). Conversion rates were determined on the crude mixture by ${ }^{1} \mathrm{H}$ NMR, with $1,3,5-$ trimethoxybenzene as the internal standard. After evaporation of the solvent, the final product was purified by column chromatography on silica gel.

Methyl 2-(3-phenyl-4-oxo-2-tosyl-2,3,4,5,6,7-hexahydro$1 \mathrm{H}$-isoindol-1-yl)acetate (3a). Compound 3a was obtained in $90 \%$ yield $(98 \mathrm{mg})$ after purification with an heptane/ethyl acetate gradient $\left(\mathrm{R}_{\mathrm{f}}=0.3\right.$ in heptane/ethyl acetate $1: 1)$. ${ }^{1} \mathrm{H}$ NMR $\left(\mathrm{CDCl}_{3}\right): \delta 7.66(\mathrm{~d}, J=8.2 \mathrm{~Hz}, 2 \mathrm{H})$, 7.3-7.2 (7H), $5.61(\mathrm{~d}, J=1.2 \mathrm{~Hz}, 1 \mathrm{H}, \mathrm{N}-\mathrm{CHPh}), 5.03(\mathrm{br}, \mathrm{m}$ $\mathrm{NCH}), 3.74(\mathrm{~s}, 3 \mathrm{H}, \mathrm{OMe}), 3.17(\mathrm{dd}, J=15.9$ and $4.0 \mathrm{~Hz}$, $\left.1 \mathrm{H}, \mathrm{CH}_{2} \mathrm{CO}_{2} \mathrm{Me}\right), 2.93(\mathrm{~d}, J=15.9$ and $7.9 \mathrm{~Hz}, 1 \mathrm{H}$, $\left.\mathrm{CH}_{2} \mathrm{CO}_{2} \mathrm{Me}\right), 2.42(\mathrm{~s}, \mathrm{Me}), 2.4-2.2(\mathrm{~m}, 4 \mathrm{H}), 2.0-1.9(\mathrm{~m}$, $2 \mathrm{H}) ;{ }^{13} \mathrm{C}$ NMR $\left(\mathrm{CDCl}_{3}\right): \delta 194.4(\mathrm{CO}), 170.7\left(\mathrm{CO}_{2} \mathrm{Me}\right)$, 158.5 (C=C-CO), 144.0 (C), 139.9 (C), 135.0 (C), 134.4 (C), 129.8, 127.8, 127.7, 127.6, 68.2 (NCHPh), 65.6 (NCH), 52.1 (OMe), 40.1 ( $\left.\mathrm{CH}_{2} \mathrm{CO}_{2} \mathrm{Me}\right), 37.7\left(\mathrm{CH}_{2} \mathrm{CO}\right), 23.6,22.9$, 21.5 (Me) ppm. HRMS (ESI) calcd. for $\mathrm{C}_{24} \mathrm{H}_{25} \mathrm{NO}_{5} \mathrm{~S}$ $[\mathrm{M}+\mathrm{Na}]^{+}$; 462.1351, found: 462.1360. IR (neat) $v 1732$, $1673 \mathrm{~cm}^{-1}$.

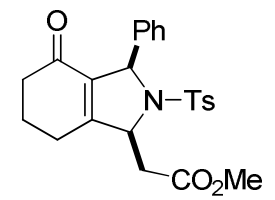

Methyl 2-(3-(4-chlorophenyl)-4-oxo-2-tosyl-2,3,4,5,6,7hexahydro- $1 \mathrm{H}$-isoindol-1-yl)acetate $(3 \mathrm{~b})$. Compound $3 \mathrm{~b}$ was obtained in $93 \%$ yield $(110 \mathrm{mg})$ after purification with an heptane/ethyl acetate gradient $\left(\mathrm{R}_{\mathrm{f}}=0.3\right.$ in cyclohexane/ethyl acetate $1: 1) .{ }^{\mathrm{q}} \mathrm{H} \mathrm{NMR}\left(\mathrm{CDCl}_{3}\right): \delta 7.65(\mathrm{~d}$, 
$\mathrm{J}=8.0 \mathrm{~Hz}, 2 \mathrm{H}), 7.3-7.2(6 \mathrm{H}), 5.55(\mathrm{~d}, J=1.2 \mathrm{~Hz}, 1 \mathrm{H}, \mathrm{N}-$ CHAr), 5.0 (br, m, NCH), 3.74 (s, 3H, OMe), 3.16 (dd, $J=$ 16.0 and $\left.4.0 \mathrm{~Hz}, 1 \mathrm{H}, \mathrm{CH}_{2} \mathrm{CO}_{2} \mathrm{Me}\right), 2.95(\mathrm{~d}, J=15.9$ and 8.0 $\mathrm{Hz}, 1 \mathrm{H}, \mathrm{CH}_{2} \mathrm{CO}_{2} \mathrm{Me}$ ), 2.43 (s, Me), 2.4-2.2 (m, 4H), 2.0-1.9 $(\mathrm{m}, 2 \mathrm{H}) ;{ }^{3} \mathrm{C} \mathrm{NMR}\left(\mathrm{CDCl}_{3}\right): \delta 194.3(\mathrm{CO}), 170.6\left(\mathrm{CO}_{2} \mathrm{Me}\right)$, $158.8(C=\mathrm{C}-\mathrm{CO}), 144.2$ (C), 138.5 (C), 134.7 (C), 134.1 (C), 134.2 (C), $133.6(\mathrm{C}), 129.8,129.0,128.3,127.8,67.5$ (NCHAr), $65.5(\mathrm{NCH}), 52.1$ (OMe), $39.9\left(\mathrm{CH}_{2} \mathrm{CO}_{2} \mathrm{Me}\right)$, $37.7\left(\mathrm{CH}_{2} \mathrm{CO}\right), 23.6,22.9,21.5(\mathrm{Me}) \mathrm{ppm}$. HRMS (ESI) calcd. for $\mathrm{C}_{24} \mathrm{H}_{24} \mathrm{ClNO}_{5} \mathrm{~S}[\mathrm{M}+\mathrm{Na}]_{1}^{+}:$496.0961, found: 496.0950. IR (neat) $\vee 1732,1675 \mathrm{~cm}^{-1}$.

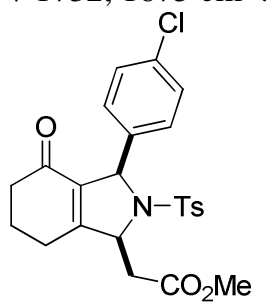

Methyl 2-(4-oxo-2-tosyl-3-(4-(trifluoromethyl)phenyl)$2,3,4,5,6,7-h e x a h y d r o-1 H$-isoindol-1-yl)acetate (3c) was obtained in $78 \%$ yield after purification with an heptane/ethyl acetate gradient $\left(\mathrm{R}_{\mathrm{f}}=0.3\right.$ in cyclohexane/ethyl acetate $1: 1) .{ }^{1} \mathrm{H}$ NMR $\left(\mathrm{CDCl}_{3}\right): \delta 7.55(\mathrm{~d}$ $J=8.2 \mathrm{~Hz}, 2 \mathrm{H}), 7.41(\mathrm{~d}, J=8.5 \mathrm{~Hz}, 2 \mathrm{H}), 7.34(\mathrm{~d}, J=8.5$ $\mathrm{Hz}, 2 \mathrm{H}), 7.20(\mathrm{~d}, J=8.2 \mathrm{~Hz}, 2 \mathrm{H}), 5.58(\mathrm{br}, \mathrm{m}, 1 \mathrm{H}, \mathrm{N}-$ CHAr), 5.0 (br, m, 1H NCH), $3.70(\mathrm{~s}, 3 \mathrm{H}, \mathrm{OMe}), 3.13$ (dd, $J=16.0$ and $4.1 \mathrm{~Hz}, 1 \mathrm{H}, \mathrm{CH}_{2} \mathrm{CO}_{2} \mathrm{Me}$ ), 2.97 (dd, $J=16.0$ and $\left.7.4 \mathrm{~Hz}, 1 \mathrm{H}, \mathrm{CH}_{2} \mathrm{CO}_{2} \mathrm{Me}\right), 2.36(\mathrm{~s}, 3 \mathrm{H}, \mathrm{Me}), 2.3-2.2(\mathrm{~m}$, $4 \mathrm{H}), 2.0-1.9(\mathrm{~m}, 2 \mathrm{H}) ;{ }^{13} \mathrm{C}$ NMR $\left(\mathrm{CDCl}_{3}\right): \delta 194.4(\mathrm{CO})$, $170.7\left(\mathrm{CO}_{2} \mathrm{Me}\right), 159.2$ (C=C-CO), $144.5(\mathrm{C}), 143.9(\mathrm{C})$, 134.6 (C), 134.2 (C), 130.0 (C), 128.2, 128.0, 125.3, 125.2, 67.9 (NCHAr), $65.8 \quad(\mathrm{NCH}), \quad 52.2 \quad(\mathrm{OMe}), \quad 40.0$ $\left(\mathrm{CH}_{2} \mathrm{CO}_{2} \mathrm{Me}\right), 37.8\left(\mathrm{CH}_{2} \mathrm{CO}\right), 23.8,23.0,21.6(\mathrm{Me}) \mathrm{ppm}$. ${ }^{9} \mathrm{~F}$ NMR $\left(\mathrm{CDCl}_{3}\right): \delta-62 \mathrm{ppm}$. HRMS (ESI) calcd. for $\mathrm{C}_{25} \mathrm{H}_{24} \mathrm{~F}_{3} \mathrm{NO}_{5} \mathrm{~S}[\mathrm{M}+\mathrm{Na}]_{1}^{+}$: 530.1225, found: 530.1221. IR (neat) $\vee 1733,1674 \mathrm{~cm}^{-1}$.

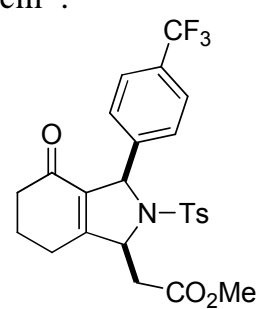

Methyl 2-(4-oxo-3-(thiophen-2-yl)-2-tosyl-2,3,4,5,6,7hexahydro- $1 \mathrm{H}$-isoindol-1-yl)acetate (3d) was obtained in $76 \%$ yield ( $85 \mathrm{mg}$ ) after purification with an heptane/ethyl acetate gradient $\left(\mathrm{R}_{\mathrm{f}}=0.3\right.$ in cyclohexane/ethyl acetate $\left.1: 1\right)$. ${ }^{1} \mathrm{H}$ NMR $\left(\mathrm{CDCl}_{3}\right): \delta 7.60(\mathrm{~d}, J=8.3 \mathrm{~Hz}, 2 \mathrm{H}), 7.19(\mathrm{~d}, J=$ $8.3 \mathrm{~Hz}, 2 \mathrm{H}), 7.08$ (dd, $J=5.2$ and $1.2 \mathrm{~Hz}, 1 \mathrm{H}), 6.99(\mathrm{dd}, J=$ 3.5 and $1.2 \mathrm{~Hz}, 1 \mathrm{H}), 6.81(\mathrm{dd}, J=5.2$ and $3.5 \mathrm{~Hz}, 1 \mathrm{H})$, 5.88 (br, m, 1H, N-CHAr), 4.91 (br, m, 1H NCH), 3.63 (s, $3 \mathrm{H}, \mathrm{OMe}$ ), 3.01 (dd, $J=16.0$ and $4.2 \mathrm{~Hz}, 1 \mathrm{H}, \mathrm{CH}_{2} \mathrm{CO}_{2} \mathrm{Me}$ ), $2.80\left(\mathrm{dd}, J=16.0\right.$ and $\left.8.0 \mathrm{~Hz}, 1 \mathrm{H}, \mathrm{CH}_{2} \mathrm{CO}_{2} \mathrm{Me}\right), 2.33(\mathrm{~s}, 3 \mathrm{H}$ $\mathrm{Me}), 2.3-2.2(\mathrm{~m}, 4 \mathrm{H}), 2.0-1.8(\mathrm{~m}, 2 \mathrm{H}) ;{ }^{13} \mathrm{C} \mathrm{NMR}\left(\mathrm{CDCl}_{3}\right)$ : $\delta 194.4(\mathrm{CO}), 170.7\left(\mathrm{CO}_{2} \mathrm{Me}\right), 159.0(C=\mathrm{C}-\mathrm{CO}), 144.4(\mathrm{C})$, 144.2 (C), 135.0 (C), 134.7 (C), 130.0 (C), 127.8, 127.0, 126.6, 125.2, 65.5 (NCHAr), 63.5 (NCH), 52.2 (OMe), 40.4 $\left(\mathrm{CH}_{2} \mathrm{CO}_{2} \mathrm{Me}\right), 37.8\left(\mathrm{CH}_{2} \mathrm{CO}\right), 23.9,23.1,21.7(\mathrm{Me}) \mathrm{ppm}$. HRMS (ESI) calcd. for $\mathrm{C}_{22} \mathrm{H}_{23} \mathrm{NO}_{5} \mathrm{~S}_{2}[\mathrm{M}+\mathrm{Na}]^{+}: 468.0916$, found: 468.0918. IR (neat) $\vee 1734,1676 \mathrm{~cm}^{-1}$.<smiles>CC(=O)CC1C2=C(C(=O)CCC2)C(c2cccs2)N1C(F)(F)F</smiles>

Methyl 2-(3-(4-methoxyphenyl)-4-oxo-2-tosyl-2,3,4,5,6,7 -hexahydro-1H-isoindol-1-yl)acetate (3e). was obtained in $82 \%$ yield $(96 \mathrm{mg})$ after purification with an heptane/diethyl ether gradient $\left(\mathrm{R}_{\mathrm{f}}=0.3\right.$ in cyclohexane/ethyl acetate $1: 1) .{ }^{1} \mathrm{H}$ NMR $\left(\mathrm{CDCl}_{3}\right): \delta 7.62(\mathrm{~d}$, $J=8.3 \mathrm{~Hz}, 2 \mathrm{H}), 7.2-7.1(\mathrm{~m}, 4 \mathrm{H}), 6.77(\mathrm{~d}, J=8.3 \mathrm{~Hz}, 2 \mathrm{H})$, 5.54 (br, m, 1H, N-CHAr), 4.95 (br, m, 1H NCH), 3.74 (s,
$3 \mathrm{H}, \mathrm{OMe}-\mathrm{Ar}), 3.68$ (s, 3H, OMe), 3.09 (dd, $J=15.9$ and $\left.4.0 \mathrm{~Hz}, 1 \mathrm{H}, \mathrm{CH}_{2} \mathrm{CO}_{2} \mathrm{Me}\right), 2.82(\mathrm{dd}, J=15.9$ and $7.8 \mathrm{~Hz}, 1 \mathrm{H}$, $\left.\mathrm{CH}_{2} \mathrm{CO}_{2} \mathrm{Me}\right), 2.37(\mathrm{~s}, 3 \mathrm{H} \mathrm{Me}), 2.3-2.2(\mathrm{~m}, 4 \mathrm{H}), 2.0-1.9(\mathrm{~m}$, $2 \mathrm{H}) ;{ }^{13} \mathrm{C}$ NMR $\left(\mathrm{CDCl}_{3}\right): \delta 194.5(\mathrm{CO}), 170.8\left(\mathrm{CO}_{2} \mathrm{Me}\right)$, 159.3 ( $C=\mathrm{C}-\mathrm{CO}), 158.3$ (C), 144.0 (C), 135.2 (C), 134.6 (C), 132.3 (C), 129.9, 128.8, 127.9, 113.7, 67.8 (NCHAr), $65.5(\mathrm{NCH}), \quad 55.3$ (OMe-Ar), 52.1 (OMe), 40.2 $\left(\mathrm{CH}_{2} \mathrm{CO}_{2} \mathrm{Me}\right), 37.8\left(\mathrm{CH}_{2} \mathrm{CO}\right), 23.8,23.0,21.6(\mathrm{Me}) \mathrm{ppm}$. HRMS (ESI) calcd. for $\mathrm{C}_{25} \mathrm{H}_{28} \mathrm{NO}_{6} \mathrm{~S}[\mathrm{M}+\mathrm{Na}]^{+}: 470.1637$, found: 470.1619 . IR (neat) $\vee 1732,1673 \mathrm{~cm}^{-1}$.

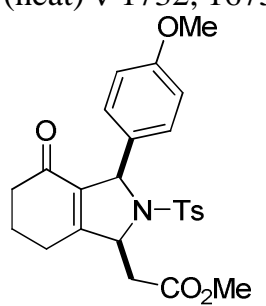

Methyl 2-(3-(naphthalen-1-yl)-4-oxo-2-tosyl-2,3,4,5,6,7hexahydro- $1 \mathrm{H}$-isoindol-1-yl)acetate $(3 \mathrm{f})$ was obtained in $83 \%$ yield $(101 \mathrm{mg})$ after purification with an heptane/ethyl acetate gradient $\left(\mathrm{R}_{\mathrm{f}}=0.3\right.$ in cyclohexane/ethyl acetate $\left.1: 1\right)$. ${ }^{\mathrm{H}} \mathrm{NMR}\left(\mathrm{CDCl}_{3}\right): \delta 8.22(\mathrm{~d}, J=8.6 \mathrm{~Hz}, 1 \mathrm{H}), 7.66(\mathrm{~d}, J=$ $8.6 \mathrm{~Hz}, 1 \mathrm{H}), 7.57(\mathrm{~d}, J=7.5 \mathrm{~Hz}, 1 \mathrm{H}), 7.46(\mathrm{ddd}, J=8.6$, 6.9 and $1.6 \mathrm{~Hz}, 1 \mathrm{H}), 7.4-7.3(\mathrm{~m}, 3 \mathrm{H}), 7.2-7.1(\mathrm{~m}, 2 \mathrm{H}), 6.85$ (d, $J=8.6 \mathrm{~Hz}, 2 \mathrm{H}), 6.36$ (br, m, 1H, N-CHAr), 5.20 (br, m, $1 \mathrm{H} \mathrm{NCH}$ ), 3.71 (s, 3H, OMe), 3.23 (dd, $J=15.9$ and $3.8 \mathrm{~Hz}$, $\left.1 \mathrm{H}, \mathrm{CH}_{2} \mathrm{CO}_{2} \mathrm{Me}\right), 3.06(\mathrm{dd}, J=15.9$ and $7.9 \mathrm{~Hz}, 1 \mathrm{H}$, $\left.\mathrm{CH}_{2} \mathrm{CO}_{2} \mathrm{Me}\right), 2.4-2.2(\mathrm{~m}, 4 \mathrm{H}), 2.15(\mathrm{~s}, 3 \mathrm{H} \mathrm{Me}), 2.0-1.9(\mathrm{~m}$, $2 \mathrm{H}) ;{ }^{13} \mathrm{C}$ NMR $\left(\mathrm{CDCl}_{3}\right): \delta 194.2(\mathrm{CO}), 171.1\left(\mathrm{CO}_{2} \mathrm{Me}\right)$, 157.5 ( $C=\mathrm{C}-\mathrm{CO}), 143.7$ (C), 136.5 (C), 136.2 (C), 134.4 (C), 133.6 (C), 131.4 (C), 129.2, 128.5, 128.3, 128.0, 126.0, $125.6,125.0,123.4,65.4$ (NCHAr), 63.2 (NCH), 52.2 (OMe), $40.1\left(\mathrm{CH}_{2} \mathrm{CO}_{2} \mathrm{Me}\right), 37.8\left(\mathrm{CH}_{2} \mathrm{CO}\right), 23.8,23.1,21.5$ (Me) ppm. HRMS (ESI) calcd. for $\mathrm{C}_{28} \mathrm{H}_{27} \mathrm{NO}_{5} \mathrm{~S}[\mathrm{M}+\mathrm{Na}]^{+}$: 512.1508, found: 512.1500. IR (neat) $\vee 1734,1677 \mathrm{~cm}^{-1}$.<smiles>CC(=O)CC1C2=C(C(=O)CCC2)C(c2cccc3ccccc23)N1[18F]</smiles>

Methyl 2-(3-(4-nitrophenyl)-4-oxo-2-tosyl-2,3,4,5,6,7hexahydro- $1 \mathrm{H}$-isoindol-1-yl)acetate $(\mathbf{3 g})$ was obtained in $47 \%$ yield ( $57 \mathrm{mg}$ ) after purification with an heptane/ethyl acetate gradient $\left(\mathrm{R}_{\mathrm{f}}=0.3\right.$ in cyclohexane/ethyl acetate $\left.1: 1\right)$. ${ }^{\mathrm{H}} \mathrm{NMR}\left(\mathrm{CDCl}_{3}\right): \delta 8.04(\mathrm{~d}, J=8.8 \mathrm{~Hz}, 2 \mathrm{H}), 7.59(\mathrm{~d}, J=$ $7.6 \mathrm{~Hz}, 2 \mathrm{H}), 7.46(\mathrm{~d}, J=8.8 \mathrm{~Hz}, 2 \mathrm{H}), 7.21(\mathrm{~d}, J=7.6 \mathrm{~Hz}$, $2 \mathrm{H}), 5.59(\mathrm{~d}, J=2.4 \mathrm{~Hz}, 1 \mathrm{H}, \mathrm{N}-\mathrm{CHAr}), 4.96(\mathrm{br}, \mathrm{m}, 1 \mathrm{H}$ $\mathrm{NCH}), 3.72(\mathrm{~s}, 3 \mathrm{H}, \mathrm{OMe}), 2.96(\mathrm{dd}, J=16.1$ and $3.9 \mathrm{~Hz}$, $1 \mathrm{H}, \mathrm{CH}_{2} \mathrm{CO}_{2} \mathrm{Me}$ ), 3.15 (dd, $J=16.1$ and $7.3 \mathrm{~Hz}, 1 \mathrm{H}$, $\mathrm{CH}_{2} \mathrm{CO} M \mathrm{Me}$, 2.38 (s, 3H Me), 2.3-2.2 (m, 4H), 2.0-1.9 (m, $2 \mathrm{H}) ;{ }^{13} \mathrm{C} \mathrm{NMR}\left(\mathrm{CDCl}_{3}\right): \delta 194.3(\mathrm{CO}), 170.7\left(\mathrm{CO}_{2} \mathrm{Me}\right)$, 159.7 ( $C=\mathrm{C}-\mathrm{CO}), 147.3$ (C), 144.8 (C), 134.3 (C), 133.8 (C), 130.2 (C), 128.9, 128.1, 123.6, 67.7 (NCHAr), 65.9 $(\mathrm{NCH}), 52.4(\mathrm{OMe}), 39.8\left(\mathrm{CH}_{2} \mathrm{CO}_{2} \mathrm{Me}\right), 37.7\left(\mathrm{CH}_{2} \mathrm{CO}\right)$, 23.8, 22.9, 21.7 (Me) ppm. HRMS (ESI) calcd. for $\mathrm{C}_{24} \mathrm{H}_{24} \mathrm{~N}_{2} \mathrm{O}_{7} \mathrm{~S}[\mathrm{M}+\mathrm{Na}]^{+}:$507.1202, found: 507.1187. IR (neat) $\vee 1733,1676 \mathrm{~cm}^{-1}$.

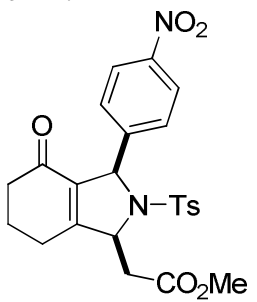

Methyl

2-(3-isopropyl-4-oxo-2-tosyl-2,3,4,5,6,7hexahydro- $1 \mathrm{H}$-isoindol-1-yl)acetate $(3 \mathrm{~h})$ was obtained in $71 \%$ yield ( $72 \mathrm{mg}$ ) after purification with an heptane/ethyl acetate gradient $\left(R_{\mathrm{f}}=0.3\right.$ in cyclohexane/ethyl acetate $\left.1: 1\right)$. ${ }^{1} \mathrm{H}$ NMR $\left(\mathrm{CDCl}_{3}\right): \delta 7.67(\mathrm{~d}, J=8.3 \mathrm{~Hz}, 2 \mathrm{H}), 7.26(\mathrm{~d}, J=$ $8.3 \mathrm{~Hz}, 2 \mathrm{H}), 4.76$ (ddd, $J=8.9,4.0$ and $1.2 \mathrm{~Hz}, 1 \mathrm{H}, \mathrm{NCH})$ 4.57 (d, $J=2.2 \mathrm{~Hz}, 1 \mathrm{H}, \mathrm{N}-\mathrm{CHAr}), 3.72$ (s, 3H, OMe), 3.04 
(dd, $J=16.3$ and $4.2 \mathrm{~Hz}, 1 \mathrm{H}, \mathrm{CH}_{2} \mathrm{CO}_{2} \mathrm{Me}$ ), 2.66 (dd, $J=$ 16.3 and $\left.8.8 \mathrm{~Hz}, 1 \mathrm{H}, \mathrm{CH}_{2} \mathrm{CO}_{2} \mathrm{Me}\right), 2.38$ (s, 3H Me), 2.3-2.2 $(\mathrm{m}, 1 \mathrm{H}), 2.1-2.2(\mathrm{~m}, 1 \mathrm{H}), 1.9-1.8(\mathrm{~m}, 1 \mathrm{H}), 0.97(\mathrm{~d}, J=7.0$ $\mathrm{Hz}, 3 \mathrm{H}, \mathrm{Me}) 0.97(\mathrm{~d}, J=7.0 \mathrm{~Hz}, 3 \mathrm{H}, \mathrm{Me}) ;{ }^{13} \mathrm{C} \mathrm{NMR}$ $\left(\mathrm{CDCl}_{3}\right): \delta 195.2(\mathrm{CO}), 171.2\left(\mathrm{CO}_{2} \mathrm{Me}\right), 159.2(\mathrm{C}=\mathrm{C}-\mathrm{CO})$ 144.1 (C), 135.2 (C), 133.8 (C), 130.0, 128.0, 71.1 (NCHAr) $65.9(\mathrm{NCH}), \quad 52.3 \quad(\mathrm{OMe}), 40.6 \quad\left(\mathrm{CH}_{2} \mathrm{CO}_{2} \mathrm{Me}\right), 37.9$ $\left(\mathrm{CH}_{2} \mathrm{CO}\right), 32.8,23.1,21.7,19.7,18.8$ (Me) ppm. HRMS (ESI) calcd. for $\mathrm{C}_{21} \mathrm{H}_{27} \mathrm{NO}_{5} \mathrm{~S}[\mathrm{M}+\mathrm{Na}]^{+}: 428.1508$, found: 428.1501. IR (neat) $\vee 1735,1672 \mathrm{~cm}^{-1}$.

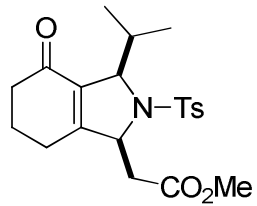

Methyl 2-(2-(4-chlorophenylsulfonyl)-4-oxo-3-phenyl$\mathbf{2 , 3}, 4,5,6,7-h e x a h y d r o-1 H$-isoindol-1-yl)acetate (3i) was obtained in $82 \%$ yield $(94 \mathrm{mg})$ after purification with an heptane/ethyl acetate gradient $\left(\mathrm{R}_{\mathrm{f}}=0.3\right.$ in cyclohexane/ethyl acetate 1:1). ${ }^{1} \mathrm{H}$ NMR $\left(\mathrm{CDCl}_{3}\right): \delta 7.50(\mathrm{~d}$ $J=8.5 \mathrm{~Hz}, 2 \mathrm{H}), 7.25(\mathrm{~d}, J=8.5 \mathrm{~Hz}, 2 \mathrm{H}), 7.5-7.1(\mathrm{~m}, 5 \mathrm{H})$, $5.51(\mathrm{~d}, J=2.1 \mathrm{~Hz}, 1 \mathrm{H}, \mathrm{N}-\mathrm{CHAr}), 4.93(\mathrm{br}, \mathrm{m}, 1 \mathrm{H} \mathrm{NCH})$, $3.58(\mathrm{~s}, 3 \mathrm{H}, \mathrm{OMe}), 2.98(\mathrm{dd}, J=15.9$ and $4.0 \mathrm{~Hz}, 1 \mathrm{H}$, $\mathrm{CH}_{2} \mathrm{CO}_{2} \mathrm{Me}$ ), 2.81 (dd, $J=15.9$ and $7.5 \mathrm{~Hz}, 1 \mathrm{H}$, $\left.\mathrm{CH}_{2} \mathrm{CO}_{2} \mathrm{Me}\right), 2.2-2.1(\mathrm{~m}, 4 \mathrm{H}), 1.9-1.7(\mathrm{~m}, 2 \mathrm{H}) ;{ }^{13} \mathrm{C} \mathrm{NMR}$ $\left(\mathrm{CDCl}_{3}\right): \delta 194.3(\mathrm{CO}), 170.6\left(\mathrm{CO}_{2} \mathrm{Me}\right), 158.2(\mathrm{C}=\mathrm{C}-\mathrm{CO})$, 139.5 (C) 139.4 , 136.5 (C), 135.1 (C), 129.4, 129.2, 128.4, 128.1, 127.8, 127.2, 68.5 (NCHAr), $65.7(\mathrm{NCH}), 52.2$ (OMe), $40.0\left(\mathrm{CH}_{2} \mathrm{CO}_{2} \mathrm{Me}\right), 37.8\left(\mathrm{CH}_{2} \mathrm{CO}\right), 23.7,23.0 \mathrm{ppm}$. HRMS (ESI) calcd. for $\mathrm{C}_{23} \mathrm{H}_{22} \mathrm{ClNO}_{5} \mathrm{~S}[\mathrm{M}+\mathrm{Na}]^{+}: 482.0805$, found: 482.0794. IR (neat) V 1732, $1674 \mathrm{~cm}^{-1}$.

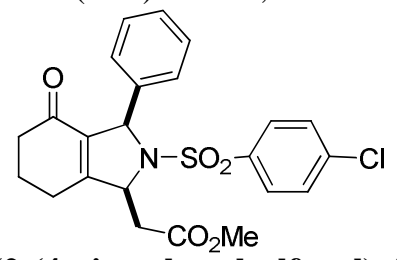

Methyl 2-(2-(4-nitrophenylsulfonyl)-4-oxo-3-phenyl$\mathbf{2 , 3}, 4,5,6,7$-hexahydro- $1 H$-isoindol-1-yl)acetate $(3 \mathbf{j})$ was obtained in $44 \%$ yield $(52 \mathrm{mg}$ ) after purification with an heptane/ethyl acetate gradient $\left(\mathrm{R}_{\mathrm{f}}=0.3\right.$ in cyclohexane/ethyl acetate 1:1). ${ }^{1} \mathrm{H}$ NMR $\left(\mathrm{CDCl}_{3}\right): \delta 8.15(\mathrm{~d}$, $J=8.8 \mathrm{~Hz}, 2 \mathrm{H}), 7.76(\mathrm{~d}, J=8.8 \mathrm{~Hz}, 2 \mathrm{H}), 7.19$ (br, m, 5H), 5.69 (d, $J=2.4 \mathrm{~Hz}, 1 \mathrm{H}, \mathrm{N}-\mathrm{CHPh}), 5.13$ (br, m, $1 \mathrm{H} \mathrm{NCH})$, $3.66(\mathrm{~s}, 3 \mathrm{H}, \mathrm{OMe}), 3.06(\mathrm{dd}, J=15.8$ and $4.4 \mathrm{~Hz}, 1 \mathrm{H}$, $\left.\mathrm{CH}_{2} \mathrm{CO}_{2} \mathrm{Me}\right), 2.94$ (dd, $J=15.8$ and $7.1 \mathrm{~Hz}, 1 \mathrm{H}$, $\left.\mathrm{CH}_{2} \mathrm{CO}_{2} \mathrm{Me}\right), 2.5-2.2(\mathrm{~m}, 4 \mathrm{H}), 2.1-2.0(\mathrm{~m}, 2 \mathrm{H}) ;{ }^{13} \mathrm{C} \mathrm{NMR}$ $\left(\mathrm{CDCl}_{3}\right): \delta 194.1(\mathrm{CO}), 170.4\left(\mathrm{CO}_{2} \mathrm{Me}\right), 157.7(\mathrm{C}=\mathrm{C}-\mathrm{CO})$, 150.2 (C), 144.4 (C), 139.0 (C), 135.0 (C), 129.0, 128.6, $128.5,127.9,124.2,68.8$ (NCHAr), $65.9(\mathrm{NCH}), 52.4$ (OMe), $39.6\left(\mathrm{CH}_{2} \mathrm{CO}_{2} \mathrm{Me}\right), 37.9\left(\mathrm{CH}_{2} \mathrm{CO}\right), 23.8,23.1 \mathrm{ppm}$. HRMS (ESI) calcd. for $\mathrm{C}_{23} \mathrm{H}_{22} \mathrm{~N}_{2} \mathrm{O}_{7} \mathrm{~S}[\mathrm{M}+\mathrm{Na}]^{+}:$493.1045, found: 493.1064. IR (neat) $\vee 1732,1675 \mathrm{~cm}^{-1}$.

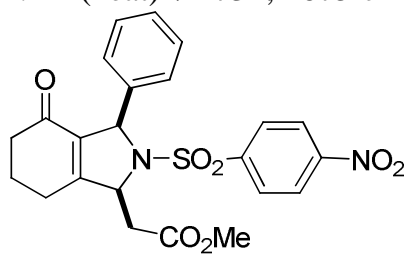

1-(2-Oxopropyl)-3-phenyl-2-tosyl-2,3,6,7-hexahydro- $1 H$ isoindol-4(5H)-one (6a) was obtained in $91 \%$ yield $(96$ $\mathrm{mg}$ ) after purification with an heptane/ethyl acetate gradient $\left(R_{f}=0.3\right.$ in cyclohexane/ethyl acetate $\left.1: 1\right)$. ${ }^{1} \mathrm{H}$ NMR $\left(\mathrm{CDCl}_{3}\right): \delta 7.61(\mathrm{~d}, J=8.3 \mathrm{~Hz}, 2 \mathrm{H}), 7.29-7.16(\mathrm{~m}, 7 \mathrm{H})$ 5.61 (d, $J=1.2,1 \mathrm{H}, \mathrm{N}-\mathrm{CHAr}$ ), 5.03 (ddd, $\mathrm{J}=7.9,4.0$ and $1.2 \mathrm{~Hz}, 1 \mathrm{H}, \mathrm{NCH}), 3.22(\mathrm{dd}, J=17.4$ and $3.3 \mathrm{~Hz}, 1 \mathrm{H}$, $\mathrm{CH}_{2} \mathrm{COMe}$ ), 2.93 (dd, $J=17.4$ and $7.9 \mathrm{~Hz}, 1 \mathrm{H}, \mathrm{CH}_{2} \mathrm{COMe}$ ), $2.34(\mathrm{~s}, 3 \mathrm{H}, \mathrm{Me}), 2.2-2.0(\mathrm{~m}, 4 \mathrm{H}), 2.13(\mathrm{~s}, 3 \mathrm{H}, \mathrm{COMe}), 1.9-$ $1.7(\mathrm{~m}, 2 \mathrm{H}) ;{ }^{13} \mathrm{C} \mathrm{NMR}\left(\mathrm{CDCl}_{3}\right): \delta 205.7$ (COMe), 194.3 (CO), 159.2 (C=C-CO), 144.1 (C), 140.3 (C), 134.8 (C), 134.0 (C), 130.0 (C), 128.3, 127.9, 129.8, 127.7, 68.1 (NCHAr), $64.4(\mathrm{NCH}), 49.2\left(\mathrm{CH}_{2} \mathrm{COMe}\right), 37.7\left(\mathrm{CH}_{2} \mathrm{CO}\right)$,
30.9 (COMe) 23.7, 22.9, 21.6 (Me) ppm. HRMS (ESI) calcd. for $\mathrm{C}_{24} \mathrm{H}_{25} \mathrm{NO}_{4} \mathrm{~S} \quad[\mathrm{M}+\mathrm{Na}]^{+}$: 446.1402, found: 446.1416. IR (neat) $\vee 1711,1671 \mathrm{~cm}^{-1}$.

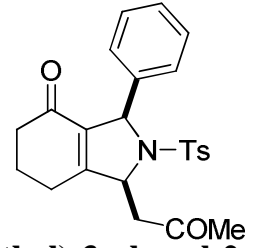

1-(2-Oxo-2-phenylethyl)-3-phenyl-2-tosyl-2,3,6,7-

hexahydro- $1 \mathrm{H}$-isoindol-4(5H)-one (6b) was obtained in $47 \%$ yield ( $57 \mathrm{mg}$ ) after purification with an heptane/ethyl acetate gradient $\left(\mathrm{R}_{\mathrm{f}}=0.3\right.$ in cyclohexane/ethyl acetate $\left.1: 1\right)$. ${ }^{1} \mathrm{H} \mathrm{NMR}\left(\mathrm{CDCl}_{3}\right): \delta 7.9-7.8(\mathrm{~m}, 1 \mathrm{H}), 7.7-7.6(\mathrm{~m}, 1 \mathrm{H}), 7.6-$ $7.5(\mathrm{~m}, 2 \mathrm{H}), 7.5-7.4(\mathrm{~m}, 1 \mathrm{H}), 7.4-7.3(\mathrm{~m}, 2 \mathrm{H}), 7.3-7.1(\mathrm{~m}$, $7 \mathrm{H}), 5.47$ (d, $J=1.7,1 \mathrm{H}, \mathrm{N}-\mathrm{CHAr}$ ), 5.17 (ddd, $\mathrm{J}=8.9,3.0$ and $1.7 \mathrm{~Hz}, 1 \mathrm{H}, \mathrm{NCH}), 3.76(\mathrm{dd}, J=17.4$ and $3.1 \mathrm{~Hz}, 1 \mathrm{H}$, $\mathrm{CH}_{2} \mathrm{CO}_{2} \mathrm{Ar}$ ), 3.44 (dd, $J=17.4$ and $8.9 \mathrm{~Hz}, 1 \mathrm{H}, \mathrm{CH}_{2} \mathrm{CO}_{2} \mathrm{Ar}$ ), $2.29(\mathrm{~s}, 3 \mathrm{H}, \mathrm{Me}), 2.2-2.1(\mathrm{~m}, 4 \mathrm{H}), 2.0-1.8(\mathrm{~m}, 2 \mathrm{H}) ;{ }^{13} \mathrm{C}$ NMR $\left(\mathrm{CDCl}_{3}\right): \delta 197.4(\mathrm{COAr}), 194.6(\mathrm{CO}), 159.8(C=\mathrm{C}-$ CO), 144.2 (C), 140.4 (C), 134.0 (C), 130.1 (C), 130.0 (C), $129.0,128.5,128.0,127.7,126.6,68.2$ (NCHAr), 65.2 $(\mathrm{NCH}), 45.3\left(\mathrm{CH}_{2} \mathrm{COAr}\right), 37.9\left(\mathrm{CH}_{2} \mathrm{CO}\right), 24.2,23.1,21.7$ (Me) ppm. HRMS (ESI) calcd. for $\mathrm{C}_{29} \mathrm{H}_{27} \mathrm{NO}_{4} \mathrm{~S}[\mathrm{M}+\mathrm{Na}]^{+}$: 508.1559, found: 508.1582. IR (neat) $v 1671 \mathrm{~cm}^{-1}$

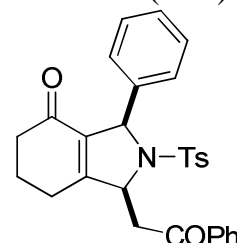

$N, N$-Dimethyl-2-(4-oxo-3-phenyl-2-tosyl-2,3,4,5,6,7-

hexahydro- $1 H$-isoindol-1-yl)acetamide (6c) was obtained in $68 \%$ yield ( $77 \mathrm{mg})$ after purification with an heptane/ethyl acetate gradient $\left(\mathrm{R}_{\mathrm{f}}=0.3\right.$ in cyclohexane/ethyl acetate 1:1). ${ }^{1} \mathrm{H}$ NMR $\left(\mathrm{CDCl}_{3}\right): \delta 7.68(\mathrm{~d}$, $J=8.3 \mathrm{~Hz}, 2 \mathrm{H}), 7.33(\mathrm{~d}, J=8.0 \mathrm{~Hz}, 1 \mathrm{H}), 7.3-7.1(\mathrm{~m}, 5 \mathrm{H})$, $6.86(\mathrm{~d}, J=8.0 \mathrm{~Hz}, 1 \mathrm{H}), 5.44(\mathrm{br}, \mathrm{m}, 1 \mathrm{H}, \mathrm{N}-\mathrm{CHAr}), 4.90(\mathrm{br}$, $\mathrm{m}, 1 \mathrm{H}, \mathrm{NCH}), 3.0-2.9\left(\mathrm{~m}, 2 \mathrm{H}, \mathrm{CH}_{2} \mathrm{CONMe}_{2}\right), 2.90(\mathrm{~s}, 3 \mathrm{H}$, $\left.\mathrm{NMe}_{2}\right), 2.84\left(\mathrm{~s}, 3 \mathrm{H}, \mathrm{NMe}_{2}\right), 2.35$ (s, 3H, Me), 2.2-1.8 (m, $6 \mathrm{H}) ;{ }^{13} \mathrm{C}$ NMR $\left(\mathrm{CDCl}_{3}\right): \delta 194.7 \quad(\mathrm{CO}), \quad 169.5$ $\left(\mathrm{CH}_{2} \mathrm{CONMe}_{2}\right), 160.7$ ( $\left.C=\mathrm{C}-\mathrm{CO}\right), 144.3$ (C), 140.4 (C), 134.4 (C), 133.7 (C), 130.1 (C), 128.3, 128.0, 127.9, 68.1 (NCHAr), $66.9(\mathrm{NCH}), 39.1\left(\mathrm{CH}_{2} \mathrm{CONMe}\right), 37.8\left(\mathrm{NMe}_{2}\right)$, $35.7\left(\mathrm{NMe}_{2}\right), 24.3,23.1,21.7(\mathrm{Me})$ ppm. HRMS (ESI) calcd. for $\mathrm{C}_{25} \mathrm{H}_{28} \mathrm{~N}_{2} \mathrm{O}_{4} \mathrm{~S}$ [M+Na] ${ }_{1}^{+}:$475.1668, found: 475.1662. IR (neat) $\vee 1674,1643 \mathrm{~cm}^{-1}$

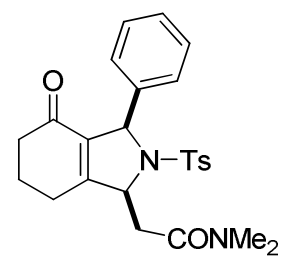

2-(4-Oxo-3-phenyl-2-tosyl-2,3,4,5,6,7-hexahydro- $1 H$ isoindol-1-yl)acetonitrile (6d) was obtained in $32 \%$ yield (32 $\mathrm{mg}$ ) after purification with an heptane/ethyl acetate gradient $\left(\mathrm{R}_{\mathrm{f}}=0.3\right.$ in cyclohexane/ethyl acetate $\left.1: 1\right) .{ }^{1} \mathrm{H}$ NMR $\left(\mathrm{CDCl}_{3}\right): \delta 7.44(\mathrm{~d}, J=8.3 \mathrm{~Hz}, 2 \mathrm{H}), 7.3-7.2(\mathrm{~m}, 2 \mathrm{H})$, 7.1-7.0 (m, 5H), $5.46(\mathrm{~d}, J=2.3 \mathrm{~Hz}, 1 \mathrm{H}, \mathrm{N}-\mathrm{CHAr}), 4.73(\mathrm{br}$, $\mathrm{m}, 1 \mathrm{H}, \mathrm{NCH}), 3.0-2.9\left(\mathrm{~m}, 2 \mathrm{H}, \mathrm{CH}_{2} \mathrm{CN}\right), 2.26(\mathrm{~s}, 3 \mathrm{H}, \mathrm{Me})$, 2.2-2.1 (m, 4H), 2.0-1.9 (m, 2H); ${ }^{3} \mathrm{C}$ NMR $\left(\mathrm{CDCl}_{3}\right)$ : $\delta 194.0(\mathrm{CO}), 154.9(C=\mathrm{C}-\mathrm{CO}), 144.6(\mathrm{C}), 138.8(\mathrm{C}), 136.7$ (C), 134.3 (C), 130.0 (C), 128.4, 128.2, 128.1, 127.9, 116.7 (CN), 68.7 (NCHAr), 64.6 (NCH), $37.9\left(\mathrm{CH}_{2} \mathrm{CN}\right), 23.9$, 23.1, 21.7 (Me) ppm. HRMS (ESI) calcd. for $\mathrm{C}_{23} \mathrm{H}_{22} \mathrm{~N}_{2} \mathrm{O}_{3} \mathrm{~S}$ $[\mathrm{M}+\mathrm{Na}]^{+}$; 429.1249 , found: 429.1258. IR (neat) $\vee 1676$, $2220 \mathrm{~cm}^{-1}$ 


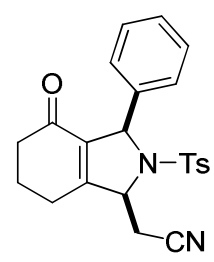

Diethyl (4-Oxo-3-phenyl-2-tosyl-2,3,4,5,6,7-hexahydro1H-isoindol-1-yl)methylphosphonate (6e) was obtained in $41 \%$ yield (53 mg) after purification with an heptane/ethyl acetate gradient $\left(\mathrm{R}_{\mathrm{f}}=0.3\right.$ in cyclohexane/ethyl acetate $\left.1: 1\right)$. ${ }^{1} \mathrm{H}$ NMR $\left(\mathrm{CDCl}_{3}\right): \delta 7.57(\mathrm{~d}, J=8.4 \mathrm{~Hz}, 2 \mathrm{H}), 7.2-7.1 \mathrm{(m}$, $7 \mathrm{H}), 5.44$ (br, m, 1H, N-CHAr), 4.76 (br, m, 1H, NCH), 4.1-3.9 (m, 4H, $\left.\mathrm{OCH}_{2}\right), 2.7-2.5\left(\mathrm{~m}, 2 \mathrm{H}, \mathrm{CH}_{2} \mathrm{PO}(\mathrm{OEt})_{2}\right)$, $2.29(\mathrm{~s}, 3 \mathrm{H}, \mathrm{Me}), 2.2-2.0(\mathrm{~m}, 4 \mathrm{H}), 1.3-1.2(\mathrm{~m}, 6 \mathrm{H}$, $\left.\mathrm{OCH}_{2} \mathrm{CH}_{3}\right) ;{ }^{13} \mathrm{C}$ NMR $\left(\mathrm{CDCl}_{3}\right): \delta 194.7(\mathrm{CO}), 159.5(\mathrm{C}=\mathrm{C}-$ CO), 144.2 (C), 140.0 (C), 135.3 (C), 134.3 (C), 130.1 (C), 128.4, 128.0, 127.9, 127.7, 68.0 (NCHAr), $64.3(\mathrm{NCH})$, $62.3\left(\mathrm{~d}, J=6.6 \mathrm{~Hz}, \mathrm{OCH}_{2}\right), 62.0\left(\mathrm{~d}, J=6.6 \mathrm{~Hz}, \mathrm{OCH}_{2}\right)$, $37.8,34.2,32.4\left(\mathrm{CH}_{2} \mathrm{PO}(\mathrm{OEt})_{2}\right), 29.8,24.1,23.2,16.4(\mathrm{~d}, \mathrm{~J}$ $=6.0 \mathrm{~Hz}, \mathrm{Me}), 16.3(\mathrm{~d}, \mathrm{~J}=6.0 \mathrm{~Hz}, \mathrm{Me}), \mathrm{ppm} \cdot{ }^{31} \mathrm{P} \mathrm{NMR}$ $\left(\mathrm{CDCl}_{3}\right)$ : 25.5. HRMS (ESI) calcd. for $\mathrm{C}_{26} \mathrm{H}_{32} \mathrm{NO}_{6} \mathrm{PS}$ $[\mathrm{M}+\mathrm{Na}]^{+}:$540.1586, found: 540.1597 . IR (neat) $\vee 1676 \mathrm{~cm}^{-}$

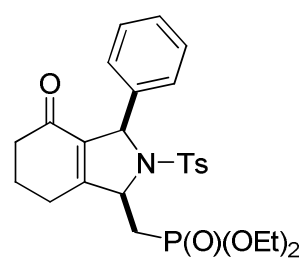

$N$-Deprotection procedure: Synthesis of methyl $\left(1 S^{*}, 3 R^{*}\right)$-4-oxo-3-phenyl-2,3,4,5,6,7-hexahydro- $1 H$ isoindol-1-yl)-acetate (3j'). To a solution of methyl $\left\{\left(1 S^{*}, 3 R^{*}\right)-2-[(4-\right.$ nitrophenyl)sulfonyl]-4-oxo-3-phenyl$2,3,4,5,6,7$-hexahydro- $1 H$-isoindol-1-yl $\}$ acetate $\mathbf{3 j}(30 \mathrm{mg}$, $0.06 \mathrm{mmol}$ ) and $\mathrm{K}_{2} \mathrm{CO}_{3}$ (35 mg, $0.25 \mathrm{mmol}, 4.0$ equiv.) in $\mathrm{CH}_{3} \mathrm{CN}$-DMSO $(95: 5)(1 \mathrm{~mL})$ at room temperature was added $\mathrm{PhSH}(23 \mu \mathrm{L}, 0.22 \mathrm{mmol})$. The reaction mixture was heated at $40{ }^{\circ} \mathrm{C}$ for $2 \mathrm{~h}$. The crude mixture was diluted with AcOEt $(10 \mathrm{~mL})$ and $\mathrm{HCl} 1 N(10 \mathrm{~mL})$ and the layers were separated. The aqueous layer was basified with solid $\mathrm{K}_{2} \mathrm{CO}_{3}$ $(\mathrm{pH} 10-11)$ and extracted with AcOEt $(3 \times 10 \mathrm{~mL})$. The combined organic extracts were dried over $\mathrm{MgSO}_{4}$, filtered, and concentrated in vacuo to provide $3 \mathbf{j}$ ' (12 $\mathrm{mg}, 66 \%)$.

${ }^{1} \mathrm{H}$ NMR $\left(\mathrm{CDCl}_{3}\right): \delta 7.34(\mathrm{~d}, J=7.1 \mathrm{~Hz}, 2 \mathrm{H}), 7.30(\mathrm{dd}, J=$ 7.1 and $6.9 \mathrm{~Hz}, 2 \mathrm{H}), 7.22(\mathrm{t}, J=6.9 \mathrm{~Hz}, 1 \mathrm{H}), 5.25(\mathrm{~s}, 1 \mathrm{H}, \mathrm{N}-$ CHPh), 4.59 (dd, $J=4.4$ and $4.1 \mathrm{~Hz}, 1 \mathrm{H}, \mathrm{NCH}), 3.71(\mathrm{~s}, 3 \mathrm{H}$ $\mathrm{OMe}$ ), 2.79 (dd, $J=15.6$ and $4.1 \mathrm{~Hz}, 1 \mathrm{H}, \mathrm{CH}_{2} \mathrm{CO}_{2} \mathrm{Me}$ ), 2.60 (dd, $J=15.6$ and $\left.4.4 \mathrm{~Hz}, 1 \mathrm{H}, \mathrm{CH}_{2} \mathrm{CO}_{2} \mathrm{Me}\right), 2.51-2.30$ $(\mathrm{m}, 4 \mathrm{H}), 2.22(\mathrm{br}, \mathrm{s}, \mathrm{NH}), 1.55-1.26(\mathrm{~m}, 2 \mathrm{H}) .{ }^{13} \mathrm{C} \mathrm{NMR}$ $\left(\mathrm{CDCl}_{3}\right): \delta 195.6(\mathrm{CO}), 171.8\left(\mathrm{CO}_{2} \mathrm{Me}\right), 162.3(\mathrm{C}=\mathrm{C}-\mathrm{CO})$, 143.6 (C), 138.2 (C), 128.2, 127.5, 127.2, 65.7 (NCHPh), $63.1(\mathrm{NCH}), \quad 51.9(\mathrm{OMe}), \quad 41.0 \quad\left(\mathrm{CH}_{2} \mathrm{CO}_{2} \mathrm{Me}\right), \quad 38.2$ $\left(\mathrm{CH}_{2} \mathrm{CO}\right), 23.8,23.5$ ppm. HRMS (ESI) calcd. for $\mathrm{C}_{17} \mathrm{H}_{19} \mathrm{NO}_{3}[\mathrm{M}+\mathrm{H}]^{+}: 286.1443$, found: 286.1449 . IR (neat) v $1733,1669 \mathrm{~cm}^{-1}$.

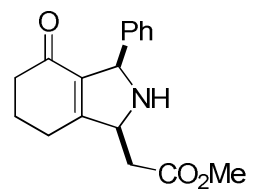

Computational methods. Geometry optimization was carried out at the B97-D level of theory ${ }^{[1]}$ with the def2TZVPP basis set. ${ }^{181}$ These calculations were accelerated using the Multipole Accelerated Resolution of Identity for J (MARI-J) approximation method, ${ }^{[19]}$ as implemented in Turbomole 6.2. ${ }^{[20]}$ LUMO have been drawn using the gOpenMol 3.00 package. ${ }^{[1]}$ The molecular orbital coefficients have been computed at the HF/STO-3G level, based on the DFT gas-phase geometries. ${ }^{[16]}$ Hückel calculations were carrried out with the Hückel simple program. ${ }^{[22}$

\section{Acknowledgements}

We are grateful to ICSN and to the Agence Nationale de la Recherche (ANR) for financial support. This work has been done within the PhoSciNet COST action.

\section{References}

[1] For recent representative examples, see: a) T. J. Watson, T. A. Ayers, N. Shah, D. Wenstrup, M. Webster, D. Freund, S. Horgan, J. P. Carey, Org. Proc. Res. \& Dev. 2003, 7, 521-532; b) P.-P. Kung, B. Huang, G. Zhang, J. Z. Zhou, J. Wang, J. A. Digits, J. Skaptason, S. Yamazaki, D. Neul, M. Zientek, J. Elleraas, P. Mehta, M.-J. Yin, M. J. Hickey, K. S. Gajiwala, C. Rodgers, J. F. Davies II, M. R. Gehring, J. Med. Chem. 2010, 53, 499-503. c) S. Van Goethem, P. Van der Veken, V. Dubois, A. Soroka, A.-M. Lambeir, X. Chen, A. Haemers, S. Scharpé, I. De Meester, K. Augustyns, Bioorg. Med. Chem. Lett. 2008, 18, 41594162.

[2] a) D. Achard, S. Grisoni, E. James-Surcouf, J.-L. Malleron, A. Morgat, J.-F. Peyronel, J.-F. Sabuco, M. Tabart WO 95/04040 (Rhône-Poulenc Rorer S.A.) 1995. b) J.-D. Bourzat, A. Commerçon, N. Dereu, P. Mailliet, F. Sounigo-Thompson, J.-P. Martin, M. Capet, M. Cheve WO98/29390 (Rhône Poulenc-Rorer S.A.) 1998. c) P. Mailliet, C. Salagnad WO01/07408 (Aventis Pharma S.A.) 2001. d) F. Gasparini, Y. Auberson, S. Ofner WO03/047581 (Novartis Pharma GMBH) 2003. e) V. J. Santora, J. A. Covel, R. Hayashi, R. R. Webb, A. S. Ren, W. G. Chen, J. J. Duffield, J. B. Ibarra, M. Pulley, G. Semple, M. I. Weinhouse WO 2007/061741 (Arena Pharmaceuticals) 2007. f) M. Ogata, H. Matsumoto, S. Shimizu, S. Kida, H. Nakai, K. Motokawa, H. Miwa, S. Matsuura, T. Yoshida, Eur. J. Med. Chem. 1991, 26, 889-906.

[3] a) K. Popandova-Yambolieva, C. Ivanov, Synth. Commun. 1986, 16, 57-61. b) J.-L. Malleron, J.-F. Peyronel, P. Desmazeau, C. M'Houmadi, C. Planiol, Tetrahedron Lett. 1995, 36, 543-546. c) D. BonnetDelpon, J.-P. Bégué, T. Lequeux, M. Ourevitch, Tetrahedron 1996, 52, 59-70.

[4] a) S. Mutti, C. Daubié, J. Malpart, X. Radisson, Tetrahedron Lett. 1996, 37, 8743-8746. b) H. Okamura, H. Shimizu, Y. Nakamura, T. Iwagawa, M. Nakatani, Tetrahedron Lett. 2000, 41, 4147-4150.

[5] For other methods, see: a) M. Westling, T. Livinghouse, J. Am. Chem. Soc. 1987, 109, 590-592. b) K. N. Clary, M. Parvez, T. G. Back, J. Org. Chem. 2010, 75, 37513760.

[6] For recent reviews on phosphine promoted annulation reactions, see: a) X. Lu, C. Zhang, Z. Xu, Acc. Chem. Res. 2001, 34, 535-544. b) J. L. Methot, W. R. Roush, Adv. Synth. Catal. 2004, 346, 1035-1050. c) L.-W. Ye, J. Zhou, Y. Tang, Chem. Soc. Rev. 2008, 37, 1140-1152. d) B. J. Cowen, S. J. Miller, Chem. Soc. Rev. 2009, 38, 3102-3116. e) C. Nájera, J. M. Sansano, M. Yus, J. 
Braz. Chem. Soc. 2010, 21, 377-412. f) A. Marinetti, A. Voituriez, Synlett 2010, 174-194.

[7] M. Schuler, D. Duvvuru, P. Retailleau, J.-F. Betzer, A. Marinetti, Org. Lett. 2009, 11, 4406-4409.

[8] For other synthetic approaches to pyrrolines by phosphine organocatalysis, see: a) Z. Xu, X. Lu, Tetrahedron Lett. 1997, 38, 3461-3464. b) Z. Xu, X. Lu, J. Org. Chem. 1998, 63, 5031-5041. c) M. Shi, Y.-M. Xu, Eur. J. Org. Chem. 2002, 696-701. d) X.-F. Zhu, C. E. Henry, O. Kwon, Tetrahedron 2005, 61, 6276-6282. e) S. Castellano, H. D. G. Fiji, S. S. Kinderman, M. Watanabe, P. de Leon, F. Tamanoi, O. Kwon, J. Am. Chem. Soc. 2007, 129, 5843-5845. f) B. Zhang, Z. He, S. Xu, G. Wu, Z. He, Tetrahedron 2008, 64, 9471-9479. g) N. Fleury-Brégeot, L. Jean, P. Retailleau, A. Marinetti, Tetrahedron 2007, 63, 11920-11927. h) Y.Q. Fang and E. N. Jacobsen, J. Am. Chem. Soc. 2008, 130, 5660-5661. i) N. Pinto, N. Fleury-Brégeot, A. Marinetti, Eur. J. Org. Chem. 2009, 146-151.

[9] X. Fu, S. Zhang, J. Yin, T. L. McAllister, S. A. Jiang, C.-H. Tann, T. K. Thiruvengadam, F. Zhang, Tetrahedron Lett. 2002, 43, 573-576.

[10] CCDC-786106 contains the supplementary crystallographic data for this compound. These data can be obtained free of charge from CCDC, 12 Union Road, Cambridge CB2 1EZ, UK (fax (+44) 1223-336033; email deposit@ccdc.cam.uk) or via www.ccdc.cam.ac.uk/data_request/cif

[11] Portionwise addition of the phosphine, i.e. 15-20 mol\% at the beginning of the reaction and again after $8 \mathrm{~h}$ heating, can be applied to increase conversion rates.

[12] E. Piers, J. R. Grierson, C. K. Lau, I. Nagakura, Can. J. Chem. 1982, 60, 210-223.

[13] A.B. Pulipaka, S.C. Bergmeier, J. Org. Chem. 2008, 73, 1462-1467.

[14] a) Y.-L. Shi, Y.-M. Xu, M. Shi, Adv. Synth. Catal. 2004, 346, 1220-1230. b) Y.-L. Shi, M. Shi,
Tetrahedron 2006, 62, 461-475. c) V. Declerck, J. Martinez, F. Lamaty, Chem. Rev. 2009, 109, 1-48

[15] Only $\beta$-unsubstituted cyclic enones are common substrates for aza-Morita-Baylis-Hillman reactions: $M$. Shi, Y.-M. Xu, Chem. Commun. 2001, 1876-1877.

[16] a) Y. Xia, Y. Liang, Y. Chen, M. Wang, L. Jiao, F. Huang, S. Liu, Y. Li, Z.-X. Yu, J. Am. Chem. Soc. 2007, 129, 3470-3471. b) E. Mercier, B. Fonovic, C. Henry, O. Kwon, T. Dudding, Tetrahedron Lett. 2007, 48, 3617-3620. c) Y. Liang, S. Liu, Y. Xia, Y. Li, Z.-X. Yu, Chem. Eur. J. 2008, 14, 4361-4373.

[17] S. Grimme, J. Comput. Chem. 2006, 27, 1787-1799.

[18] F. Weigend, M. Häser, H. Patzelt, R. Ahlrichs, Chem. Phys. Lett. 1998, 294, 143-152.

[19] M. Sierka, A. Hogekamp, R. Ahlrichs, J. Chem. Phys. 2003, 118, 9136-9148.

[20] R. Ahlrichs, M. Bär, M. Häser, H. Horn, C. Kölmel, Chem. Phys. Lett. 1989, 162, 165-169.

[21] a) L. Laaksonen, J. Mol. Graph. 1992, 10, 33-34. b) D. L. Bergman, L. Laaksonen, A. Laaksonen, J. Mol. Graph. Model. 1997, 15, 301-306.

[22] Hückel simple version 4.0. Jean-Yves Magna 1998. http://www.jymagna.com 


\section{FULL PAPER}

An Easy Stereoselective Synthesis of

Hexahydroisoindol-4-ones under Phosphine

Catalysis.

Adv. Synth. Catal. Year, Volume, Page - Page

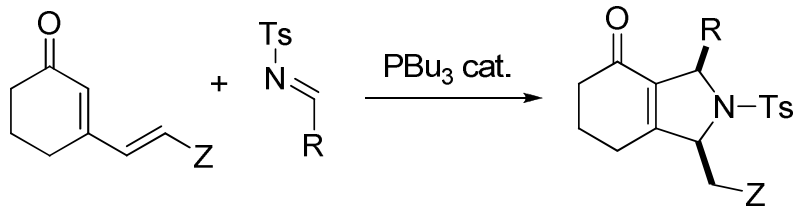

14 examples,

Deepti Duvvuru, Jean-François Betzer,* Pascal

$41-93 \%$ yields

Retailleau, Gilles Frison and Angela Marinetti* 